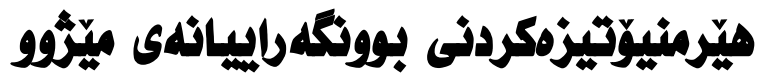

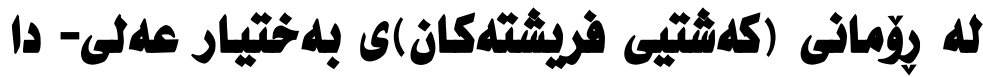

زانكوّى كَهرميان- كوّليّجى يُهرودردهى بنهرِت- بلهى زمانى كوردى

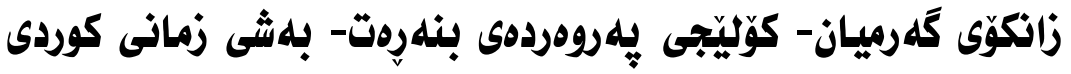

ئيبراهيم عdبلوليرهحمان مdحموود

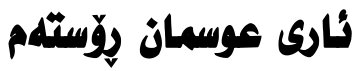

\section{ariothman@garmian.edu.krd}

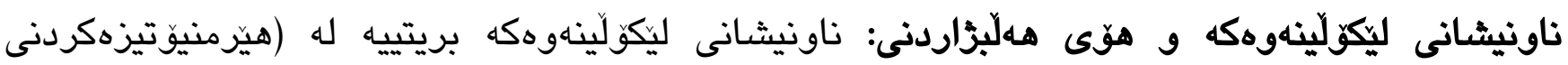

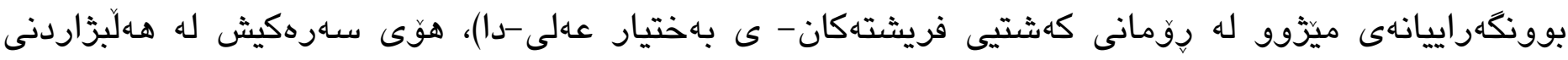

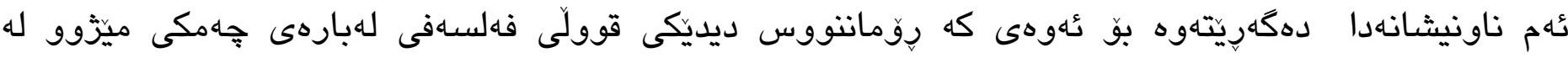

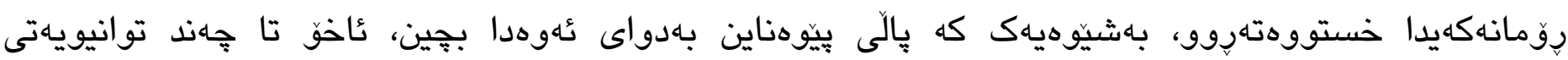

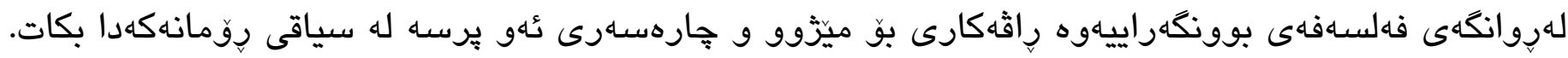
كليله ووشُه: كهشتيى فريشتكان، ميزوو، نووسهار.

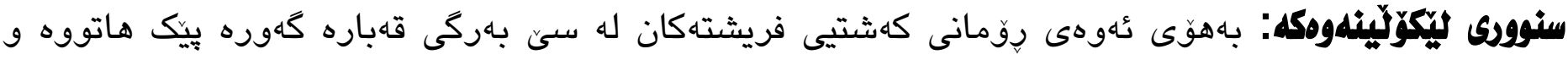

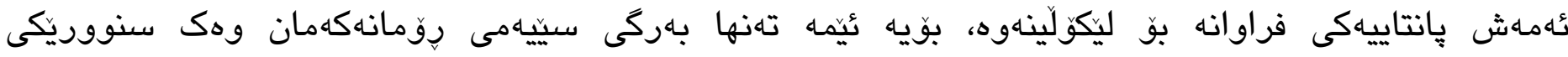

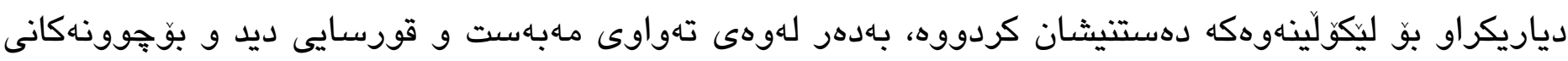
روّمانتووس لهم بهركهدا جرِيووهتهوه، ئهمه بهو مانايه نييه، كه بهركَكانى ترى رِومانهكه له ئاستيكى نزمدا بن.

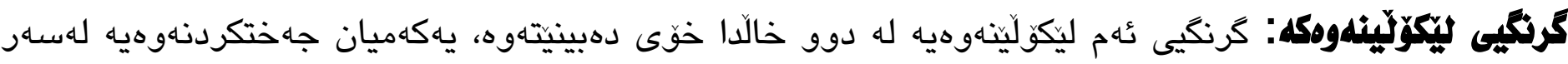

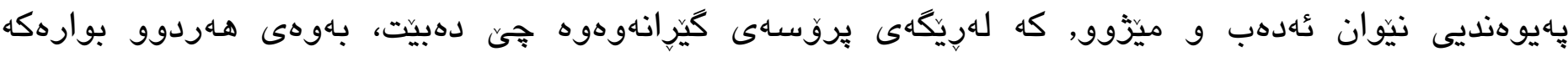




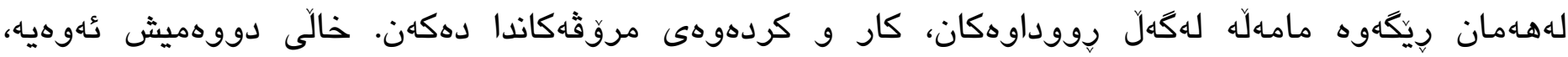

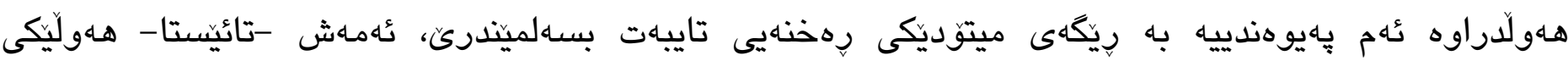
تاقانهى لهم جوّرهيه لهبارهى دهقى رِومانى كوردييهوه ئهنجام درابيت.

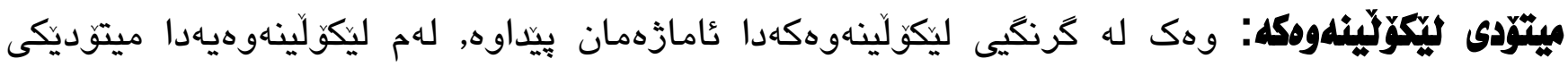
رهخنهيى تايبهت كيراوهته بهر، كه تئويش بريتييه له (هيرمنيوّتيكى بوونكارايى) و له شوينتى ييّويستيشدا

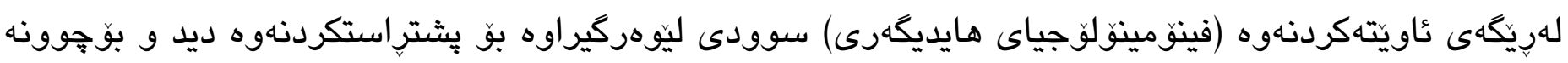
رهخنهييهكان، قورسايى هـردوو ميتودهكهش دهكهويتها بهاشى دووهمى ليكوَّلينهوهكهوه.

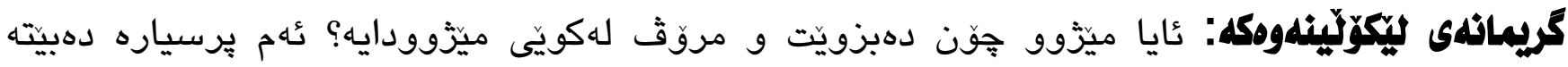

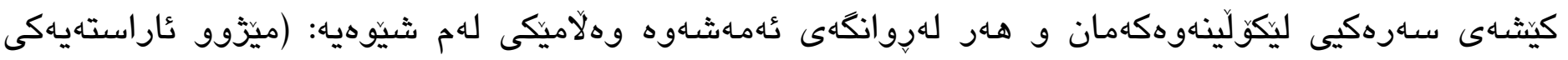

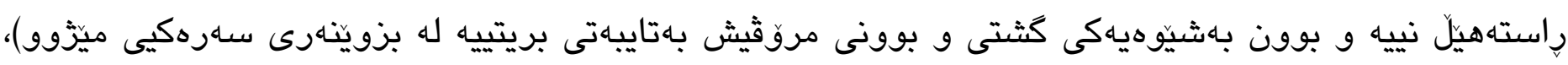

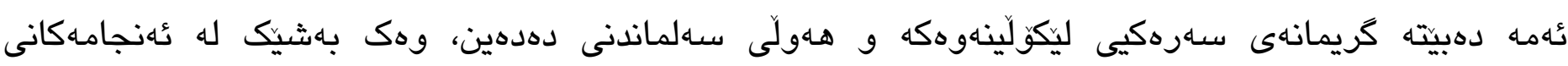
ليكوَ لَيناهو هكه.

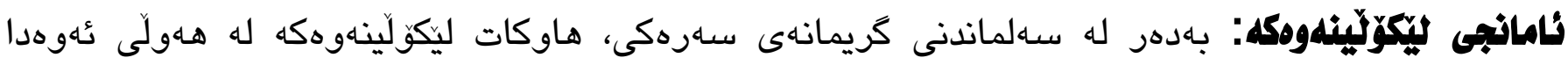
دهبيت، لهرووى تيوّريى و بِراكتيكييهوه جهوهـهر و ماهييهتى ميّزوو لهروانكاهى هارمونهتيزهكردنى بوونكهراييهوه شى بكاتهوه و تيشك بخاته سـار لايهنه ناديارهكانى بابهتهكه و روونى بكاتهوه.

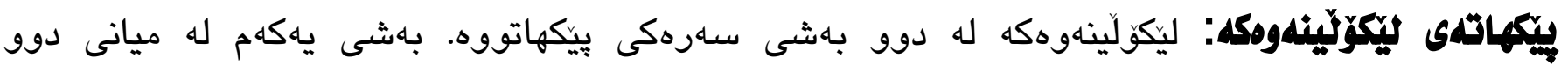
تاهوهردا تيوّريزهى جֶهمكى ميّزوو دهكات، بهوهى ماهييهتى ميزّوو رِوون كراوهتهوهو دواتر كرنكترين بوّهوونى

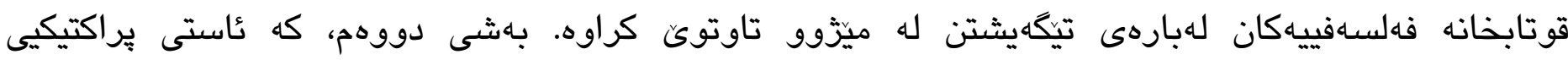

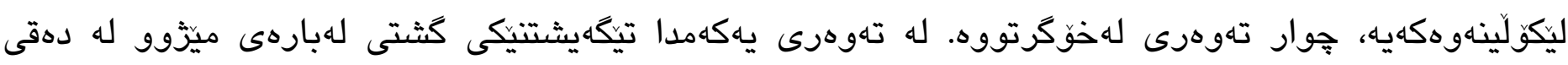

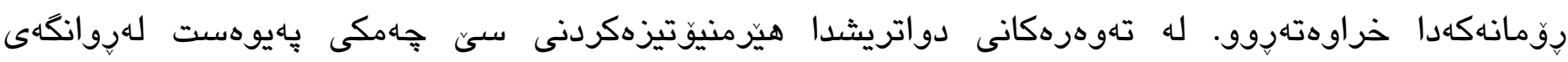
بوونكَراييهوه بهركهلكخراوه، لهوانهش: (بهديهاتنى مروق لهناو ميزّوودا و ميّزووبزوينيى و هـروهها

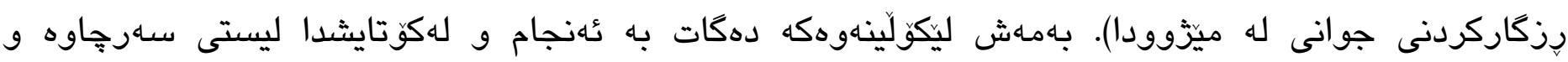
زيّدرهان بهشيّوهيهكى زانستى رِيك خراون و يووختهيهيشى به هـردوو زمانى عهرهبى و ئينكليزى بو نووسراوه. 


\section{بلششى يلككم}

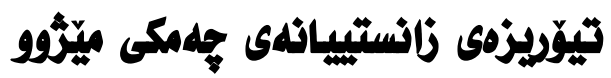

\section{تلهومرى يدكهم/ ماهييلتى ميّزُوو}

تائيستا زقورترين قسه لهبارهى زانستى ميزوو كراوه, جونكه هـموو دياردهيهك له زياندا ميزووىى هـيه,

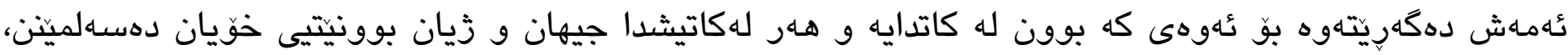

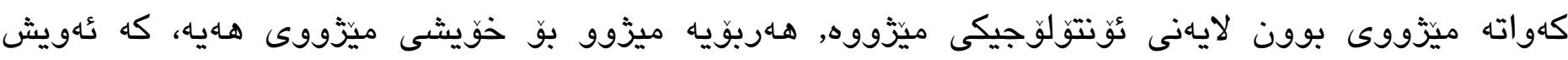

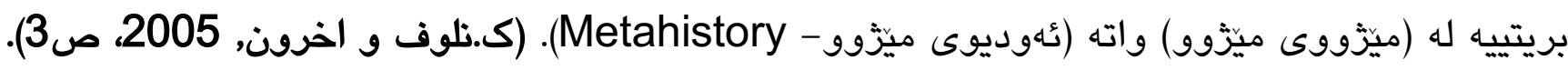

له سـارهتاييترين يِيناسـى ميزّوودا دهكوتريّيت: ميّزوو بريتييه له كَيِّانهوهى رووداوهكانى رابردوو، يان

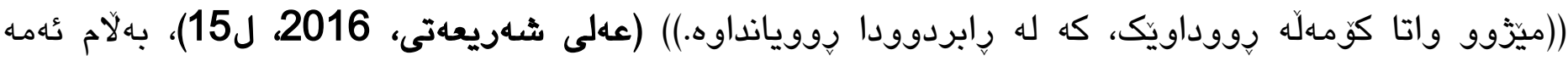

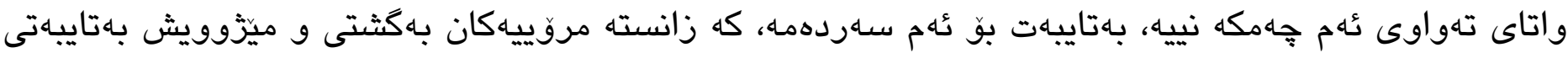

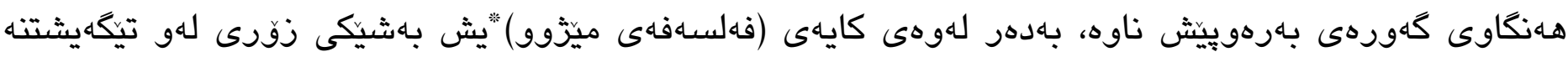

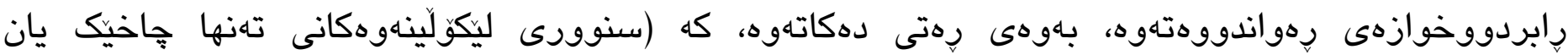

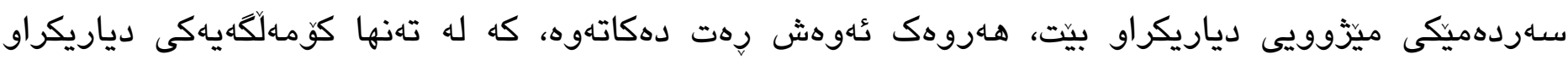
بكولّيتهوه، بهلكوو بايهخى لهوهدايه كوى بهشهكانى جيهان له يهك جوارجيّوهدا به برابردووى دوور و

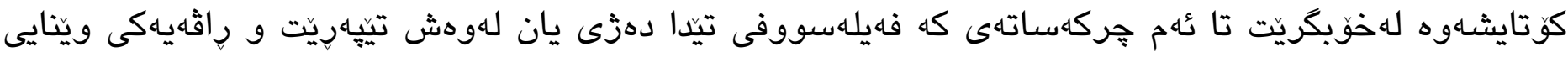

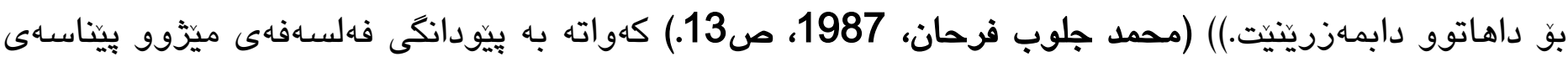

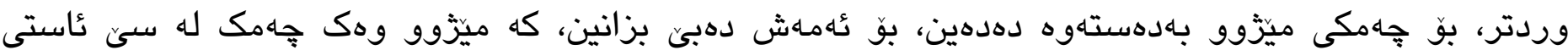

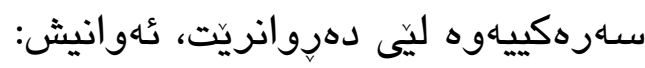

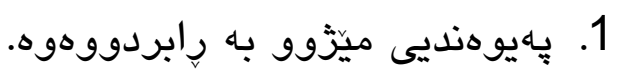

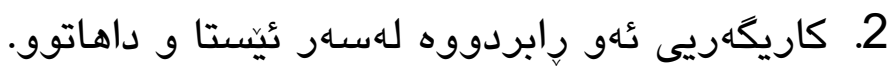

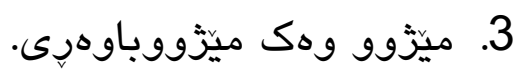

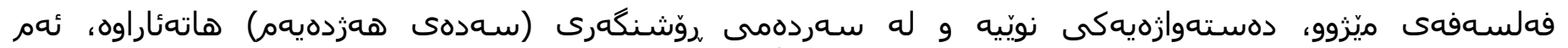

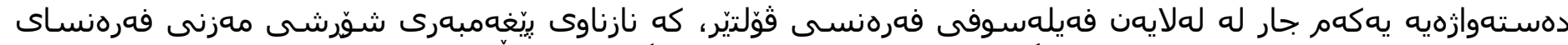

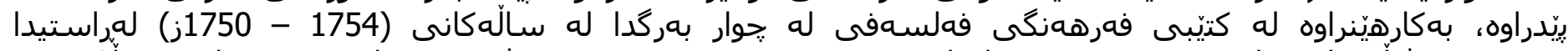

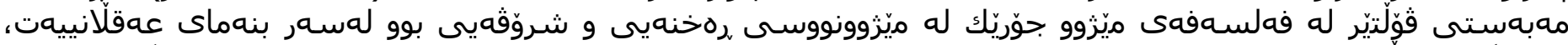

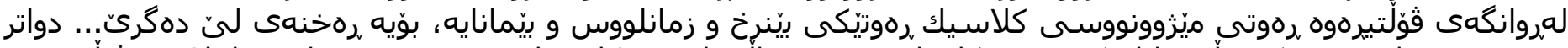

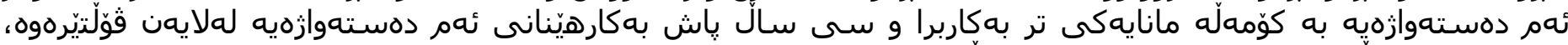

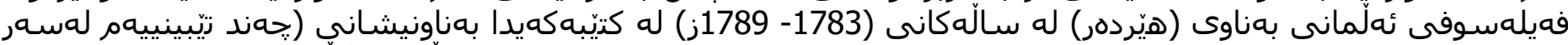

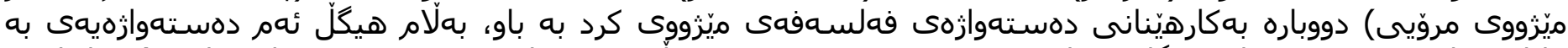

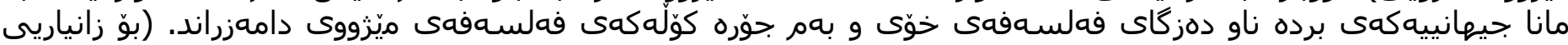

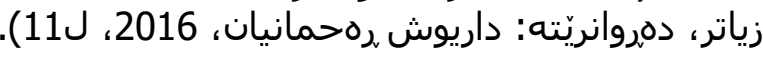




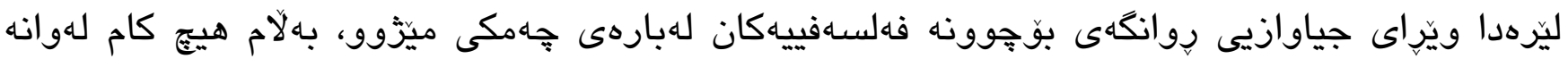

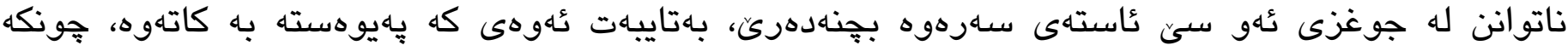
دواجار هـاموو قسهكردنيك لهسهر جهامك و ماهييهتى ميزّوو، هاوكاته به قسـكردن لهسهر جهمكيكى بهرفراوانتر، كه كيهويش جههكى كاته، بهو يِييهى تهواوى ((ميزّوو به كاتهوه بهستراوهتهوه.)) (هاشم يهحيا

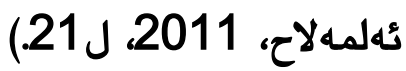

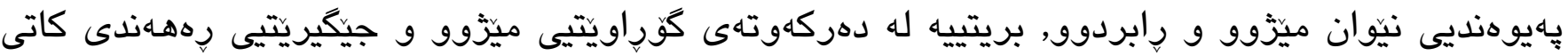

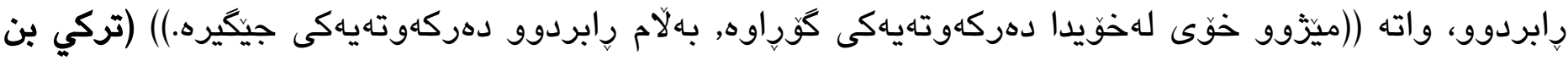

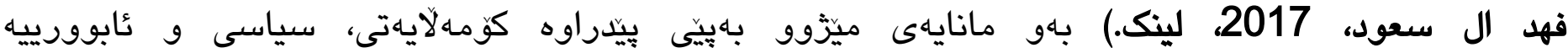

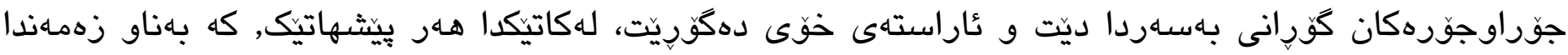

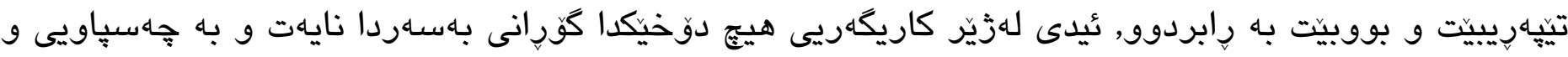

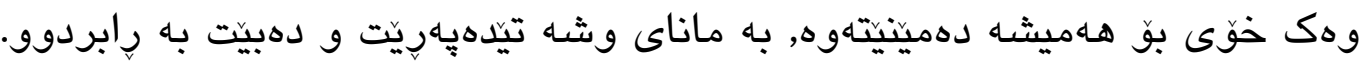

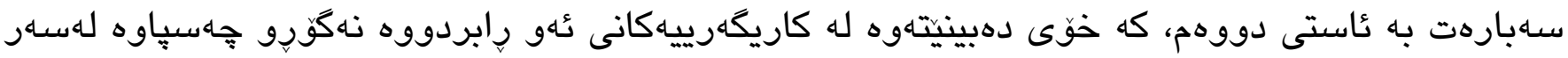

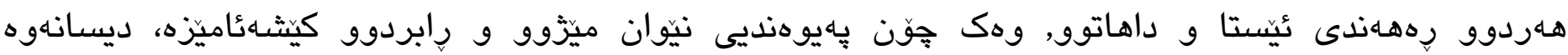

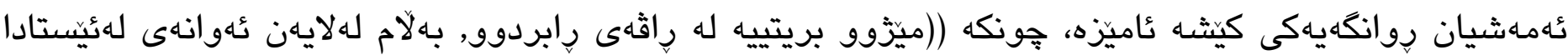
دهزين.)) (حسن مدن، 2016، لينك.) واته بهبيَ بوونى ئيستاييانهى مروث ئهتهمه بتوانريّت له رابردووى

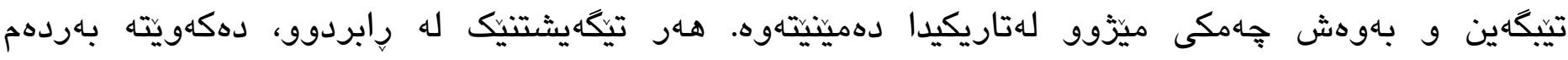

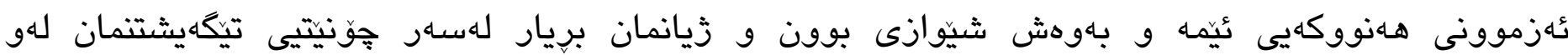

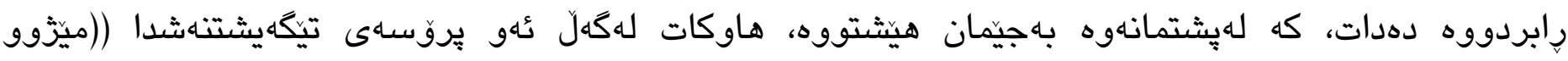

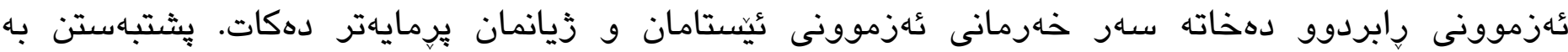
ئهزموونهكانى رِابردوو، برياردانمان له زيانى رِوزانهدا بّ تاسـان دهكات.)) (عهبدولصسهين زهرينكوب، 2011

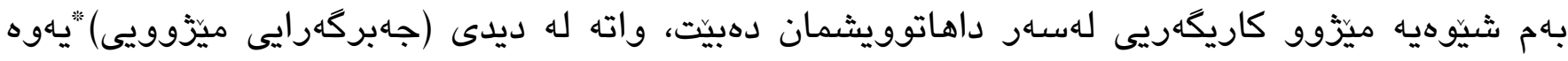

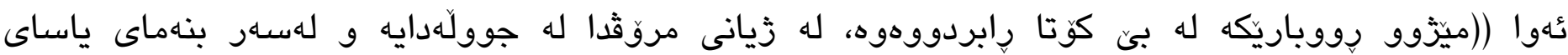

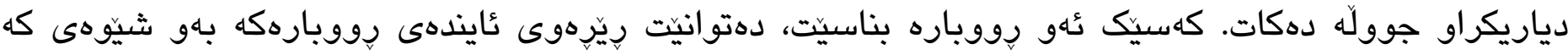

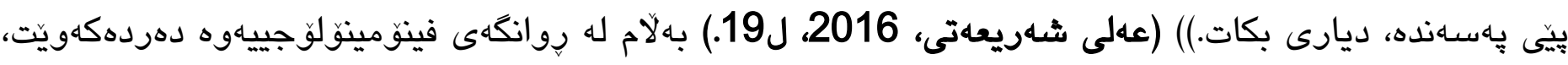

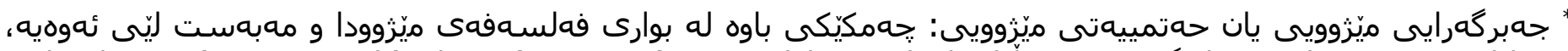

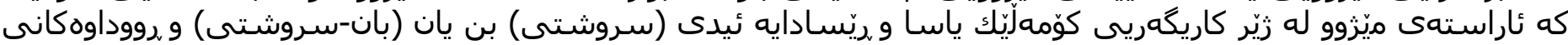

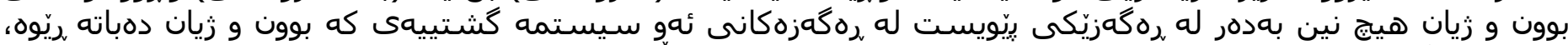

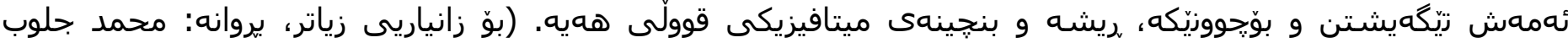




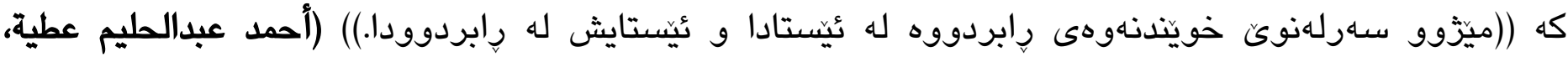

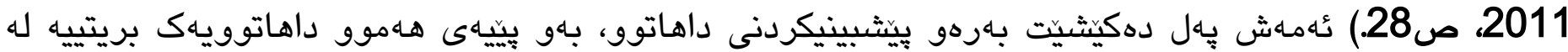

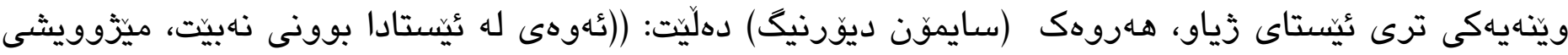

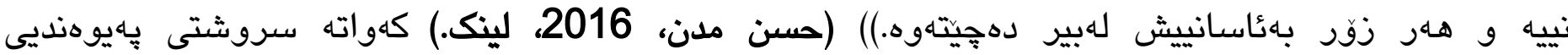

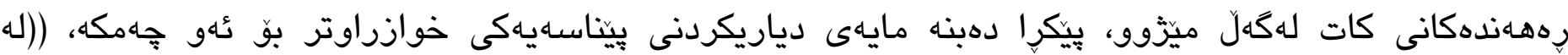

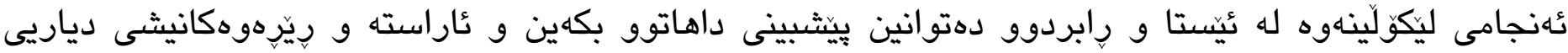
بكهين.)) (ئيحسان محهمهد ئهلحهسه، 2009، ل17.) بهم شيَّهيهش مروّق دهتوانيت هـهـت به بوون بكات و دهركى خَوى لهنيّو دوخ و رِهـهنده جياوازهكانى كاتدا بكات، بهوهى ((بههوى بيرهوهرييهوه له رابردوو تئ

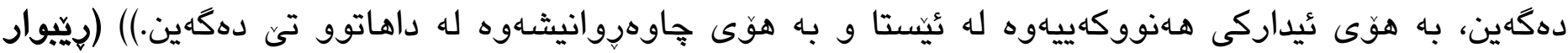

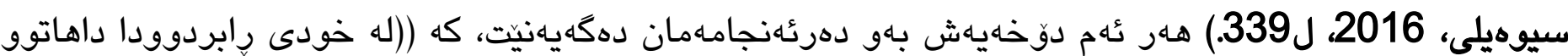
هـاهيه، داهاتووش له دهردوهى رابردووهوه لههـهان كاتدا له خودى خوّيدا رابردوو لهخوددكريت، هـمان شتيش دهربارهى يهيوهنديى يُيستا به رِابردوو و داهاتووهوه يِيكهوه دهوتريّت، بوّيه هـهوو ساتيكى كاتى ئهو سيانه

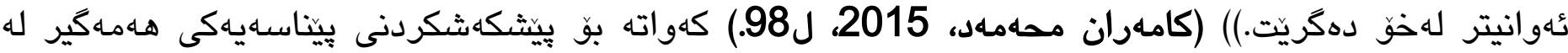

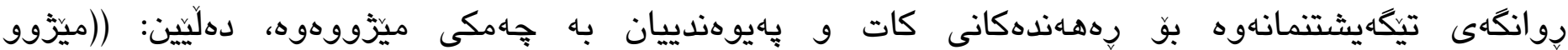

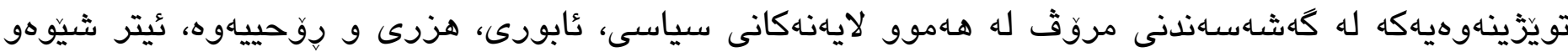

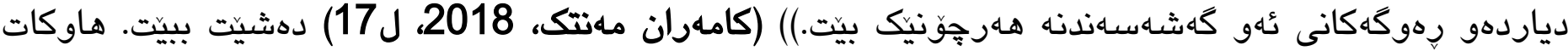

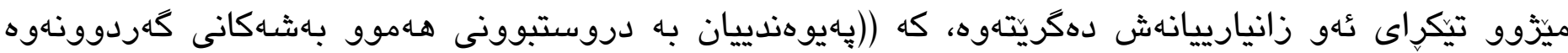

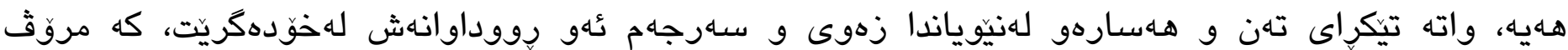

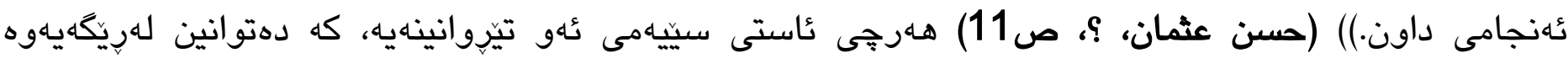

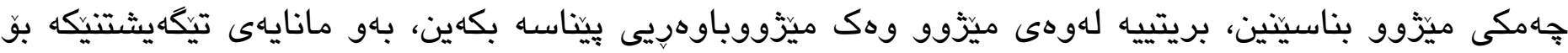

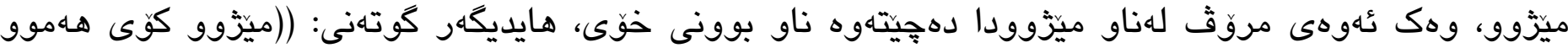

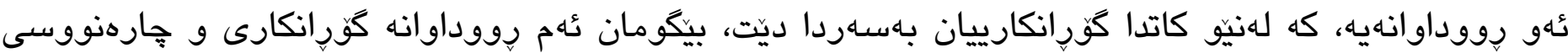
بوونى مروق و كهلتوريش دهكرناهه، كه له كَّرانكارييه سروشتييهكانهوه جياوازن.)) (مارتين هايديكهر، 2013.

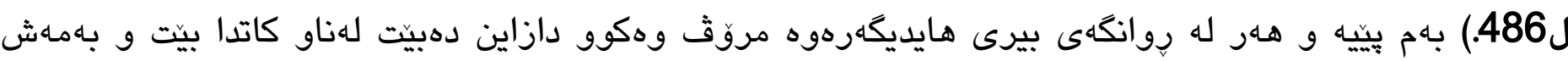
((ميّزوو دهبيت به رِوودانيكى دياريكراوى بوونى دازاين لهنيو كاتدا.)) (مارتين هايديكهر، 2013، ل468.)

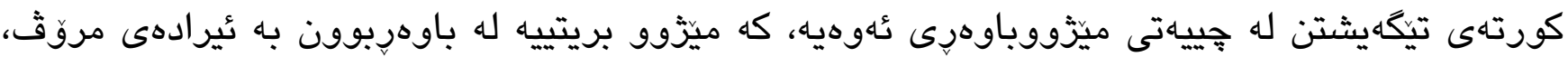

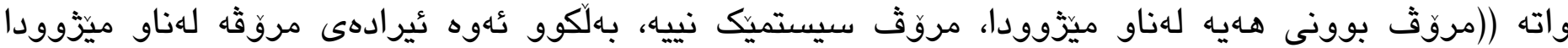

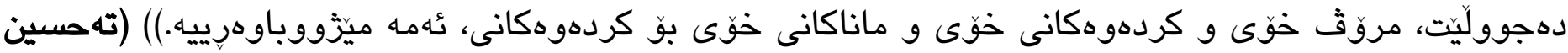

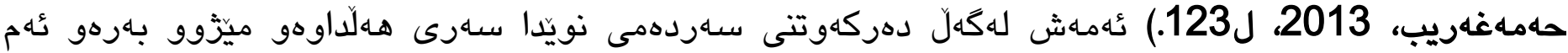




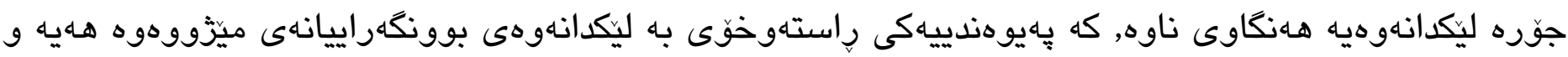

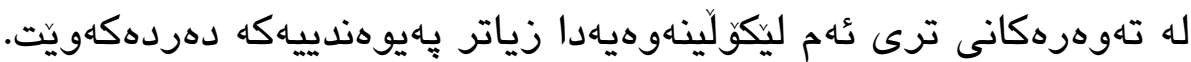

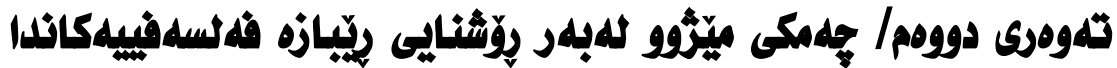

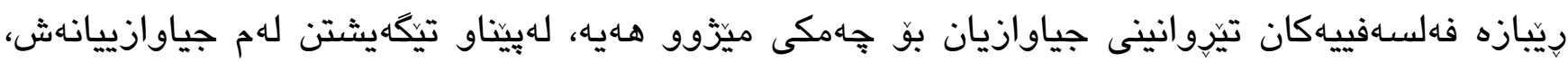

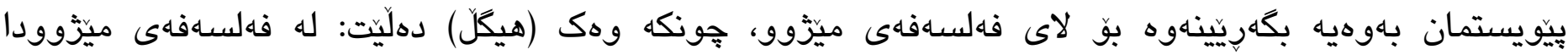

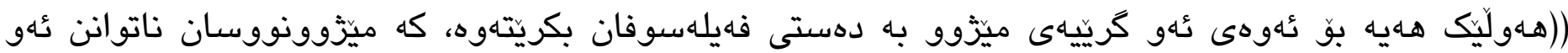

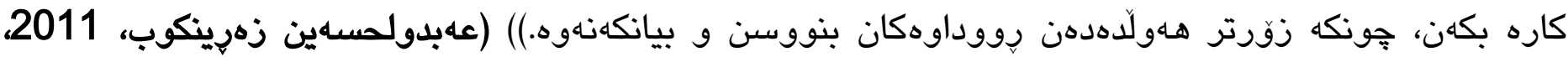

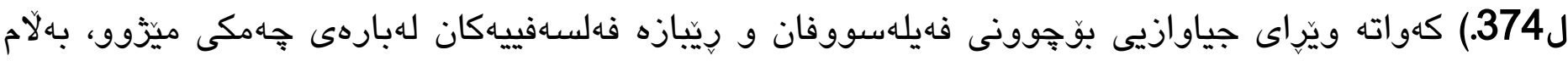
جههند رِيسايهكى كثتى له تيّروانين و تيورييهكانياندا هـيه، كه هـموويان كوكن لهسهارى و و ئهوانيش بريتين له:

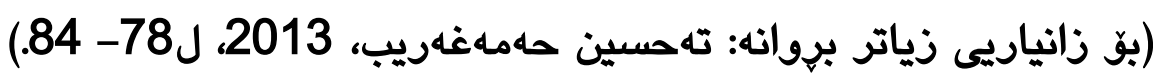

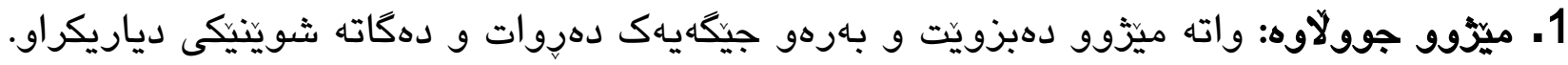

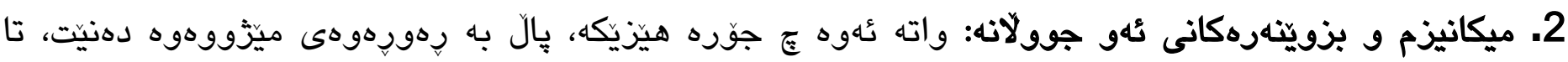
بكات بهو شوينّاءى بوّى دياريكراوه؟

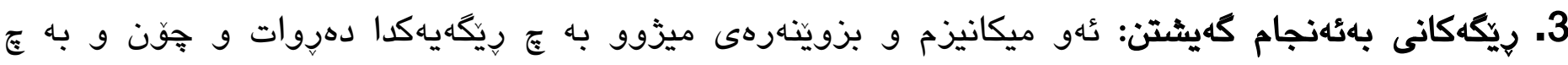

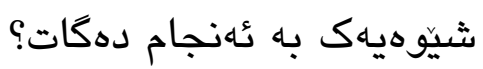

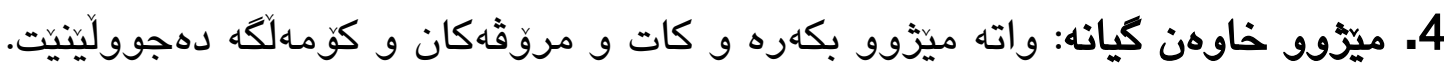

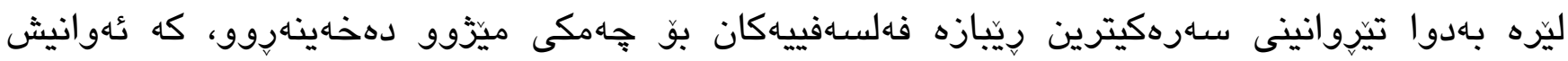

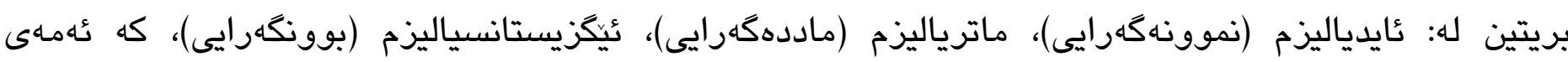

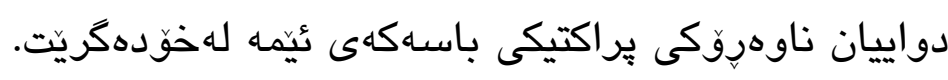

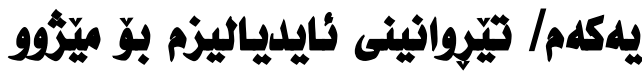

ئايدياليزم (Idealism) يان نموونهكهرايى، يهكيكه له ريّيازه ساهركييهكانى فهلسهافه و ((جهخت دهكاتهوه

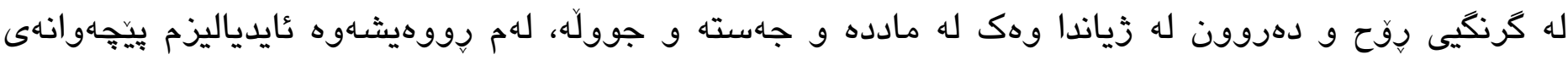

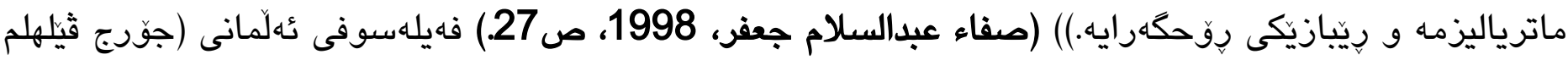

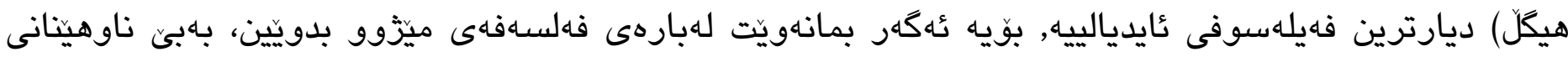

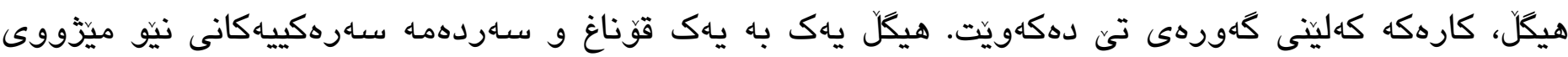

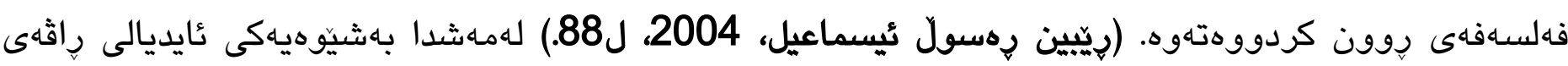


بوّ ميزّوو كردووه و يشتى به ديالهكتيك بهستووه، بوّيه فهلسهفهى هيكل به (ثايدياليزمى ديالهكتيك)

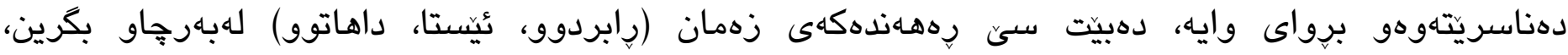

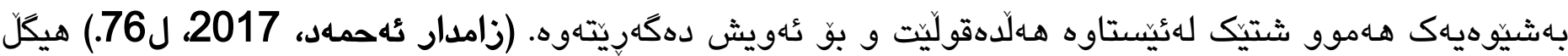

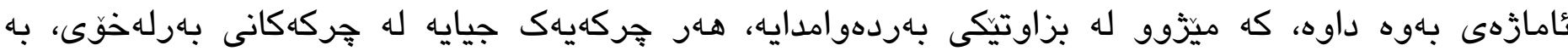

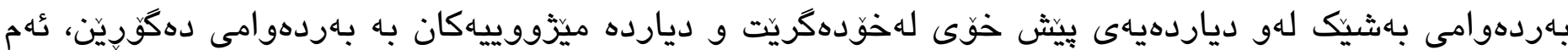

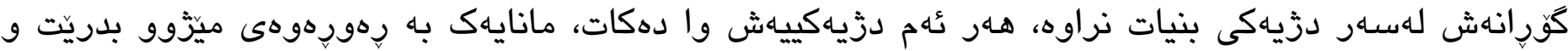

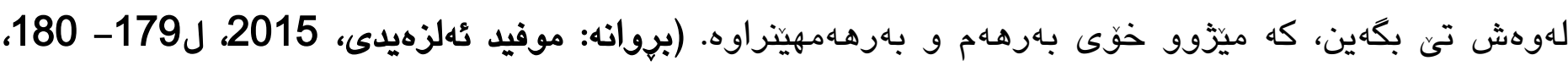

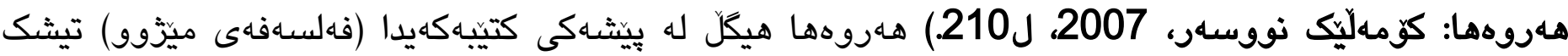

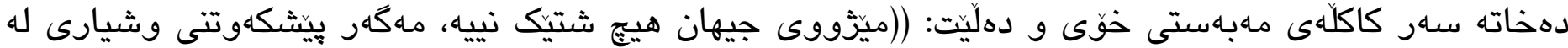

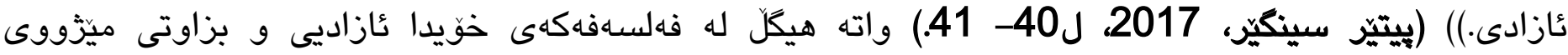

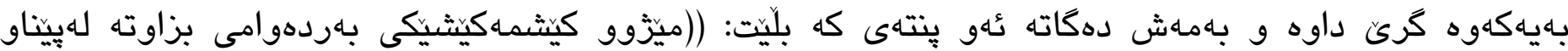
كَيشتن بـ روحىى رهها.)) (موفيد تُهلزهيلى، 2015، ل179- 180.) بهم شيّوهيه روححى رهها كوزارشته له

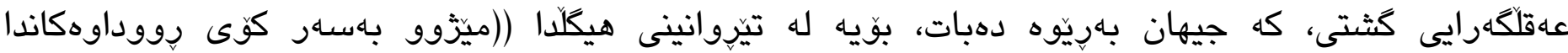
دهشكيتهوه لهروويهكى هـمـكييهوه، كه لهزيّر بارى زهمهندا نييه.)) (قيس حاتم هاني الجنابي، 2014، ل36.)

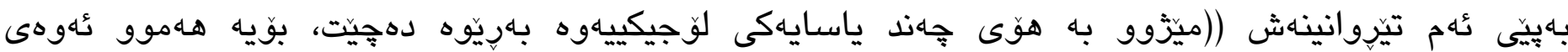

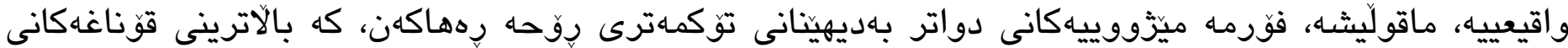
بوّ ناسينهوهى خود لهناو دهولَهى نهاتهوهيى و فهلسـاهدا دهدوزريتاهوه.)) (ئاوات تُهحمهد، 2003، ل109)

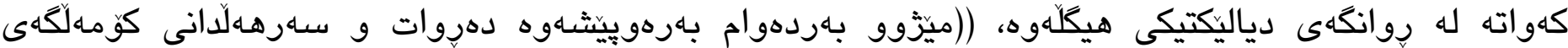
بوّرذوازى به حهتمى و دواقوناغى ميّزّوو دادهنيت.)) (محهمهد كهمال، 2016، ل73.)

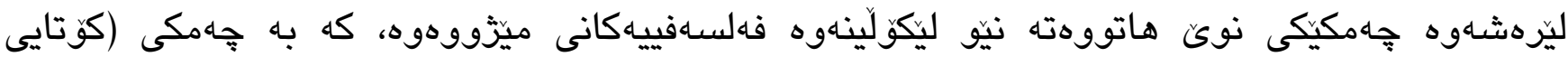

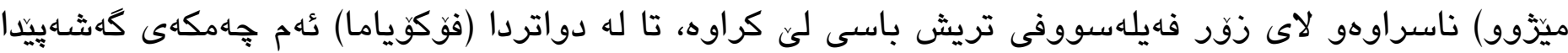
و بالاوى كردهوه، بـوهى كوتاييهاتنى ميّزوو له سيستمى ليبراليزمى رِّزئاواييدا دهبينيتهوه. (بروانه: (أ) قيس ناصر راهي، 2017، ص36- 39 و ص49... (ب) فرانسيس فوكق ياما، 2011). كهواته مـبهـتى هيكُ له

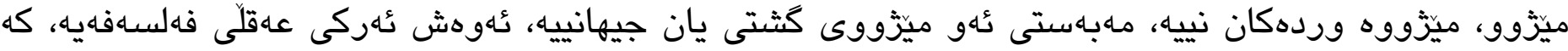
ميزّووى جيهانى به واتايهكى تهواو بناسينيتي. (داريوش رهحمانيان، 2016، ل96.) 


\section{دووم/ تيّروانينى ماترياليزم بوَ ميّزُوو}

ماترياليزم (Materialism) يان ماددكکهرايى ((ههروهك بهرامبهره مهزن و ديّرينهكه، ئايدياليزم،

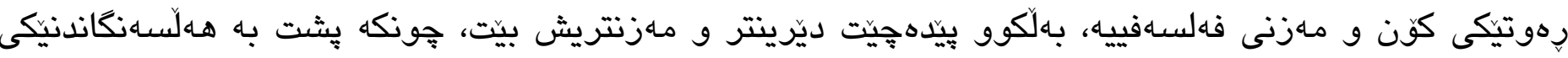

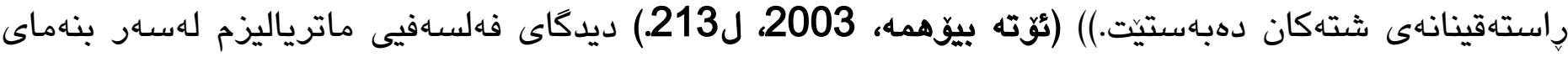

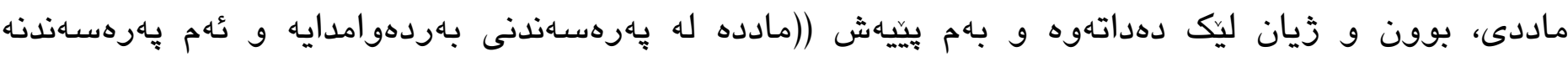

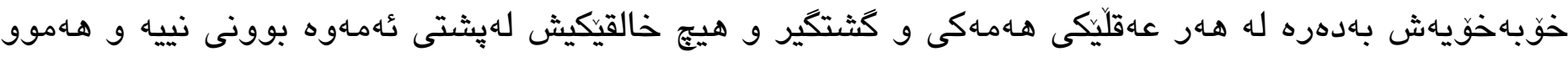

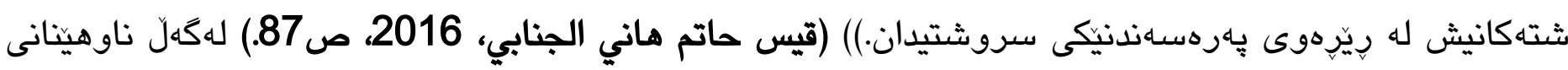

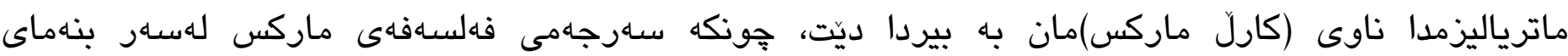
ماترياليزم دارِيزّراوهو لهمهشدا يشتى به لوّجيكى دياليكتيكى بهستووه و ئهمهشى له هيكلةوه بو ماوهتهوه،

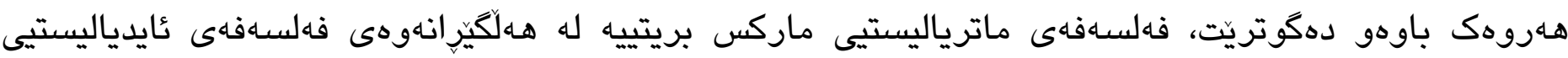

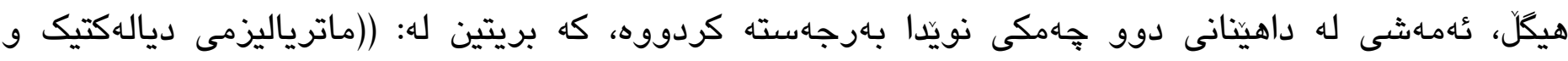

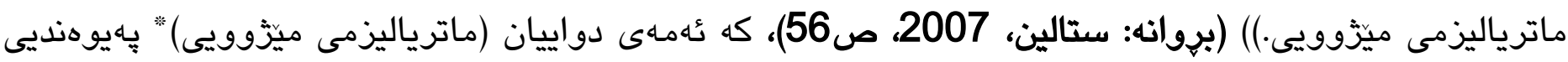

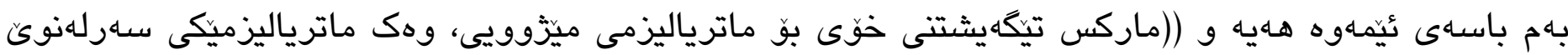

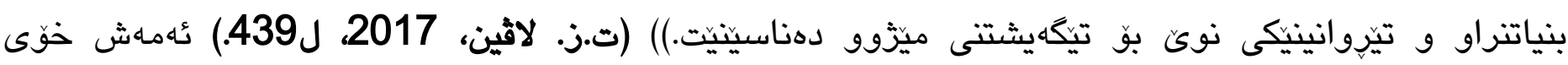

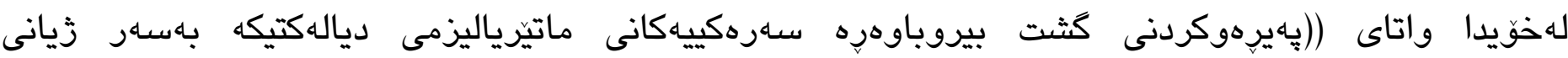

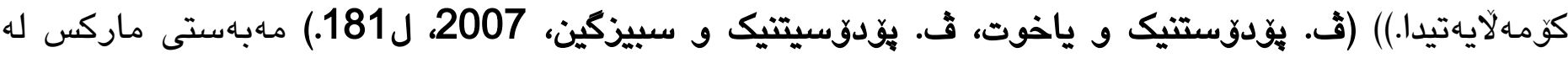

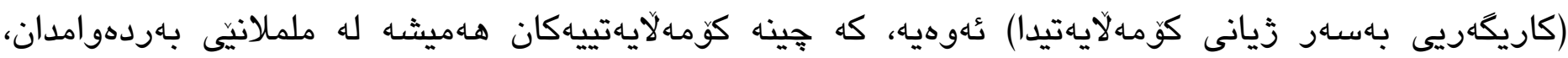

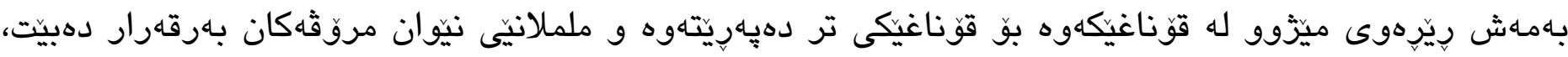

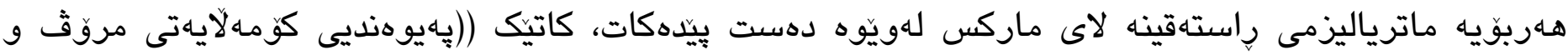

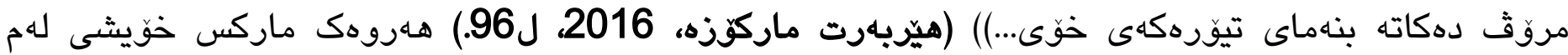

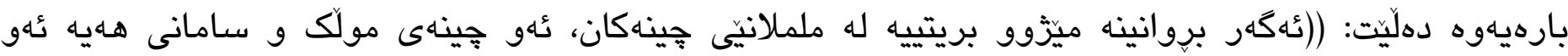

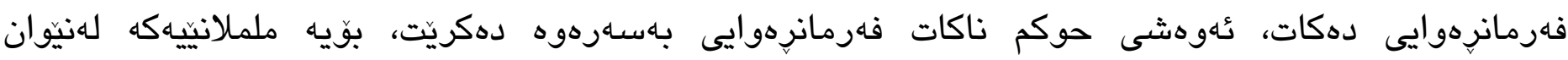

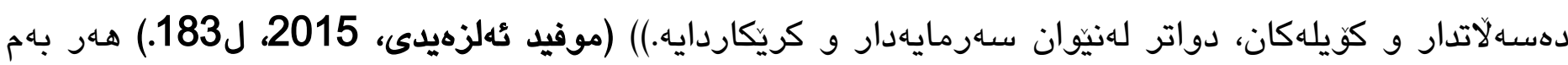

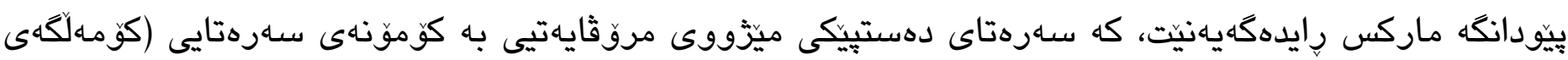

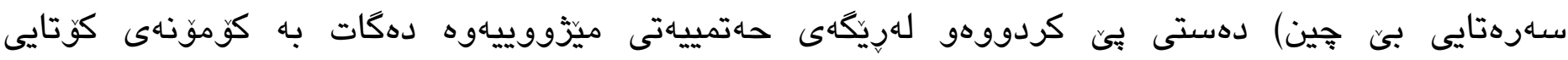

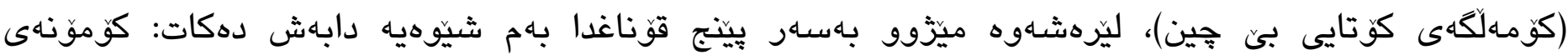

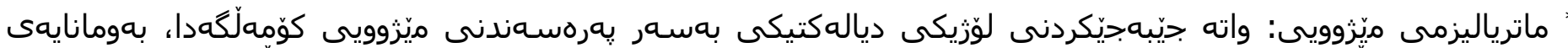

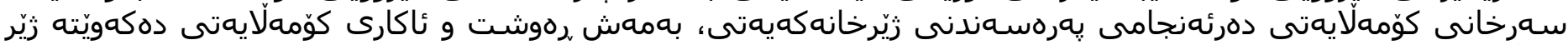

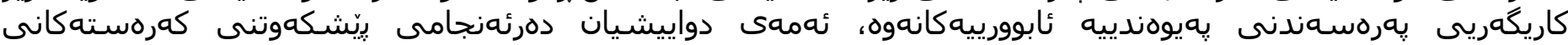

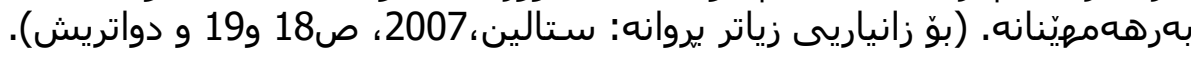
421

DOI:https://doi.org/10.26750/Vol(6).no(2).paper23 http://journal.uor.edu.krd/index.php/JUR Vol.6. No.2, September.2019 
سـهرهتايى، كويلايهتى، فيوّداليزم، سـرمايهدارى، سوسياليزم و له روونكردنهوهى ئهم قوَناغانهى ميزّوويشدا

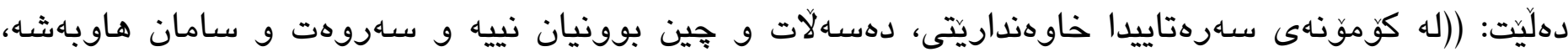

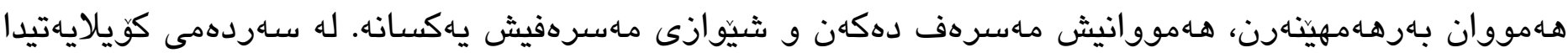

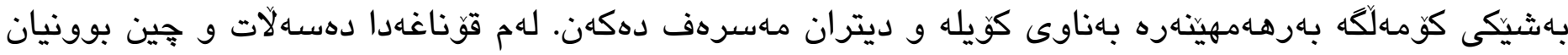

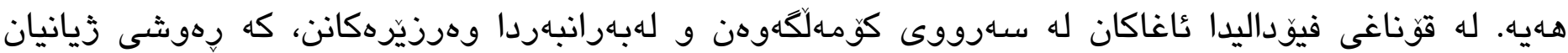

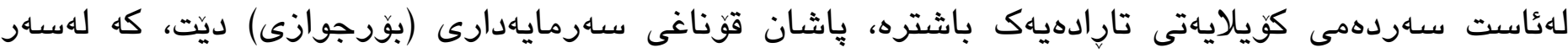
بنهاماى بازركانى و بيشـهـازيى توكمهكراو ديته عاراوهو بههوَى فراوانخوازيى خاوهن كار لهنيّوان خاوهن كارو كريكار (يّروليتهر) كهلين و جياوازيى دروست دهبيّ و له دهرئهنجامدا كريكارهكان شوّرش دهكهن و و سهارمايهاريى لهناو دهبهن و سيستمى سوّسياليزمى سهردهخهن.)) (داريوش رهحمانيان، 2016، ل102) بهم

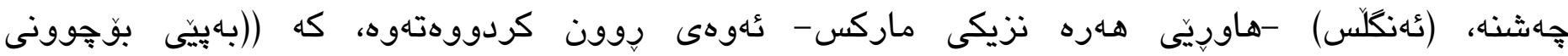

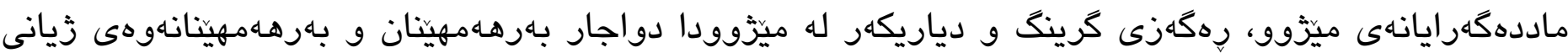

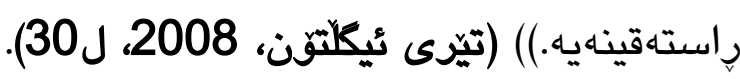

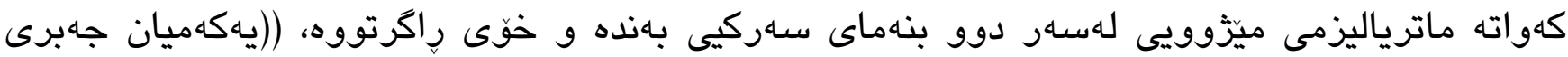

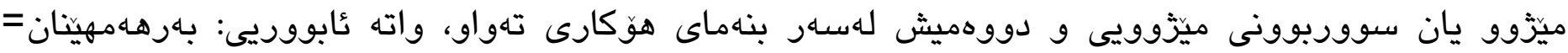

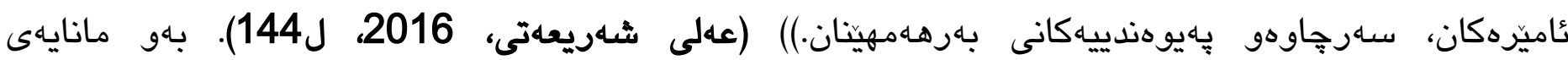

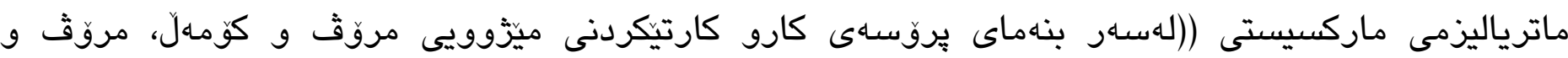
سروشت دامهزراوه)) (جان فريفل، 2006، ل46)، هـربوّيه لهرِيَّى ئهم دنيابينييه ماترياليستييهوه، تئو تيّروانينه هيومانيستييهى يِيشوو رهت دهكريتهاه، كه مروّقى وهك بوونهوهريّكى تهماشـاكهرو دهستهوهستان لههـامبهر ديارده، دهركهوتهو يِّدراوه جياوازهكانى بوون و زيان دهبينى و هـلّدسهنكاند. بهم شيّوهيه ش له جاوى ماترياليزمى ميزّووييهوه، كه ((زانستى دوزينهوهى ياسا زالَكانه بـسـهر كَّرانكارييه ميزّووييهكاندا.))

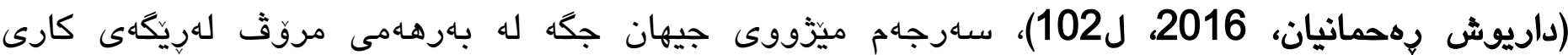
خوَيهوه، شتيكى ترى ثيهوتق نييه.

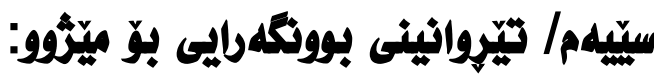

(ئيَّزيستانشياليزم) (Existentialism) يان بوونكهرايى له خودى خوّيدا فهلسهفهيه, نهك رِيَّه يان

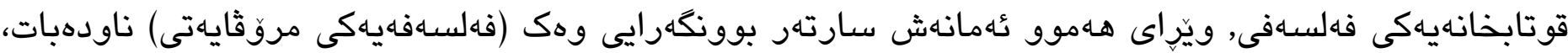

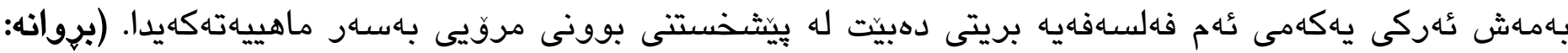
(أ) ئوميّد حهمه عهلى، 2015، ل160. (ب) ئوّته بيوّمه، 2005، ل150- 152. (ج) جان بول سارتر، 1964،

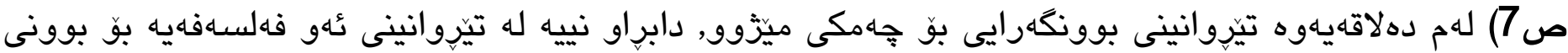

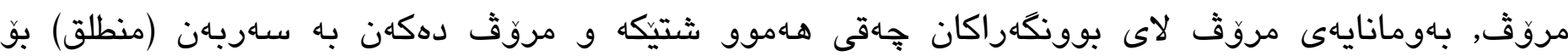




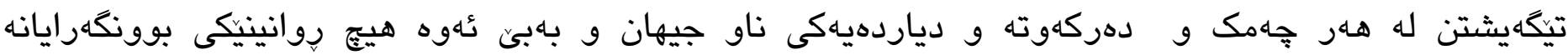

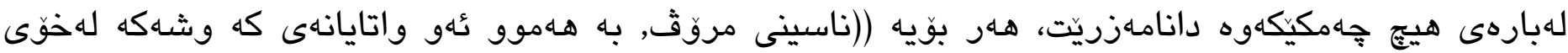

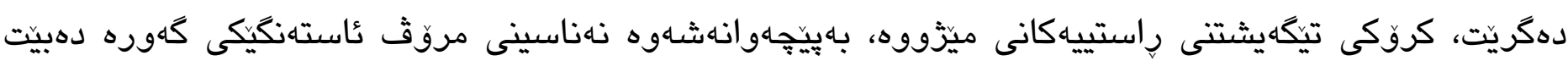

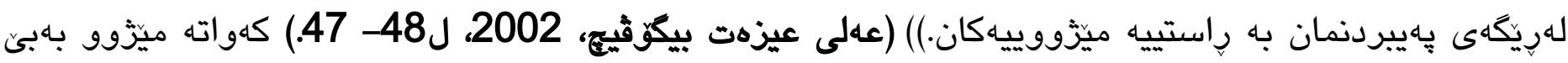

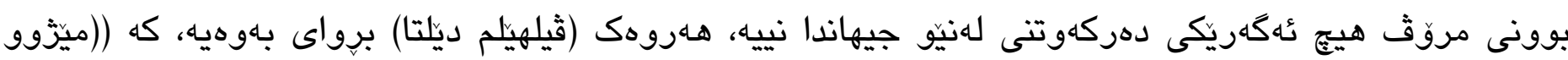

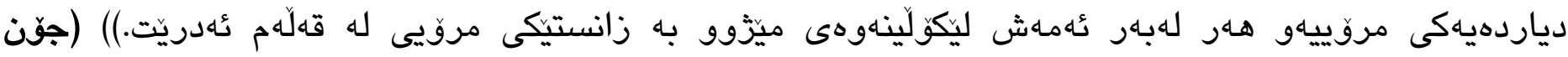

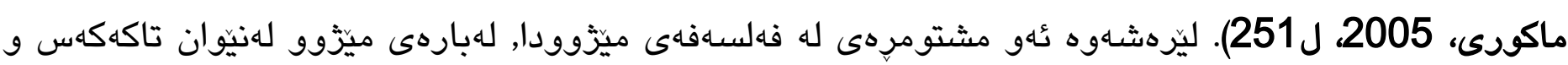
كومهلدا هـهيه, لايى بوونكَراكان يهكلايى دهبيتهوه، واته فهلسهفهى بوونكارايى كهرهستهى بيّويست دهخاته بهردهستى ئهوانهى لهروانكَيهوه بيردهكهنهوه، بوّيه به رِادهيهكى يهكلاكهرهوه توانايان بهاهـر وهلامدانهوهى

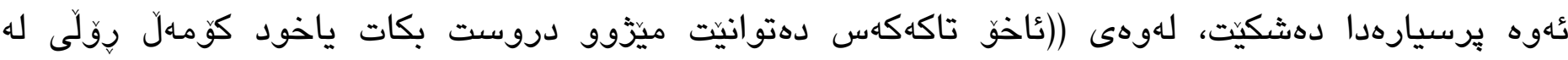

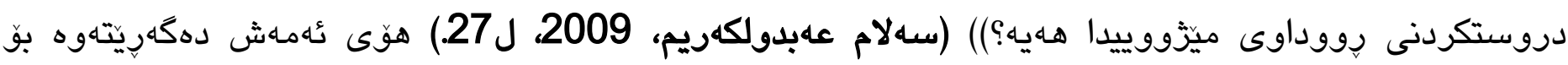

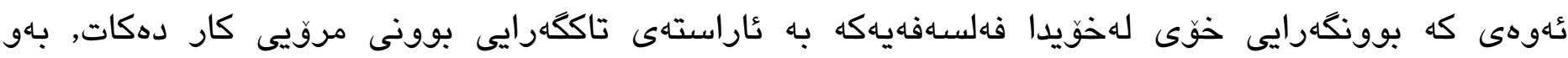

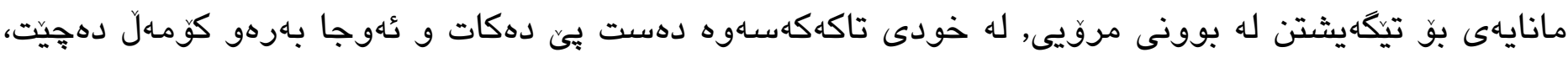

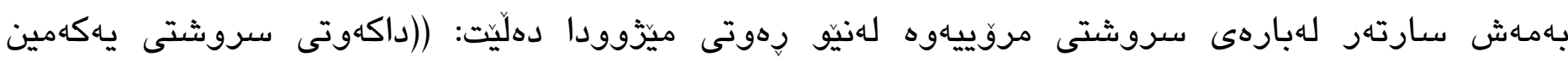
داكهوتهو داكهوتى مروّيى ع نييه بهدهر له تهنها رهكَزيَكى داكهوته سروشتييهكه, بوّيه دهبيت دان به راستيى

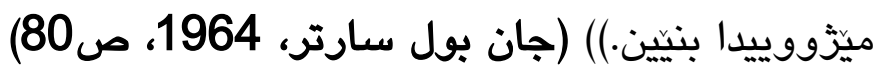
لهم روانكهوه دهبينين (كارل ياسيهرز) -وهك يهكيك له كهوره فهيلهسووفانى بوونكهرا- جهخت لهوه

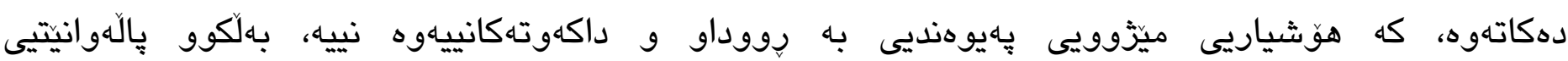

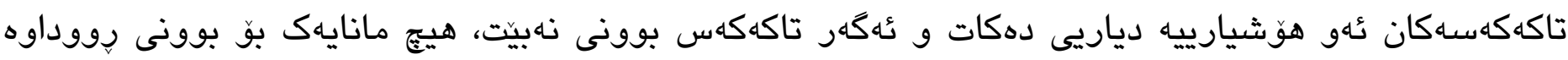

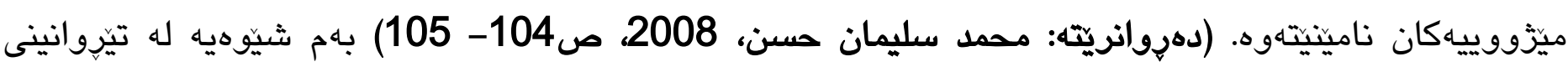

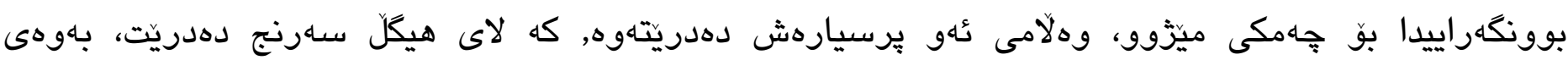

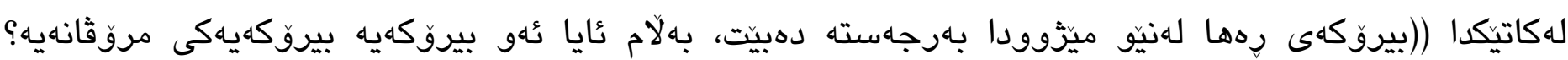

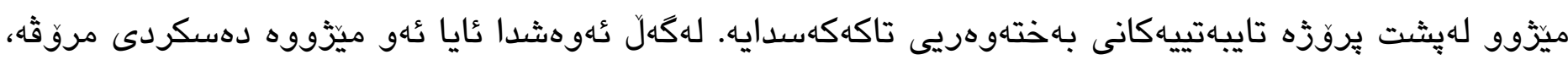

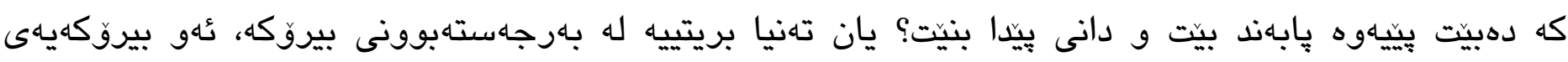

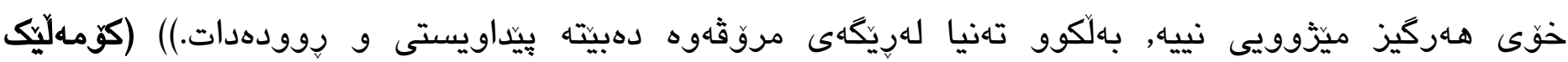
نووسهر، 2007، ل276)

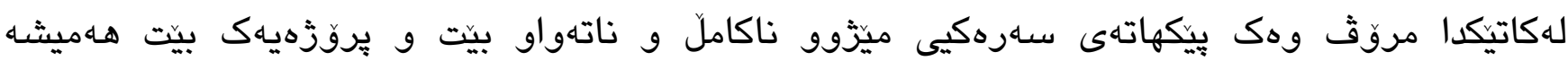

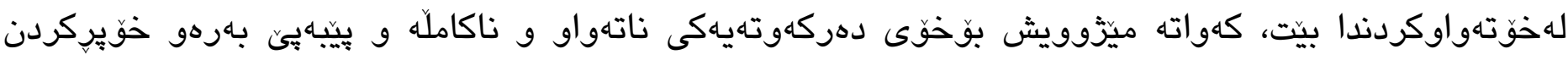

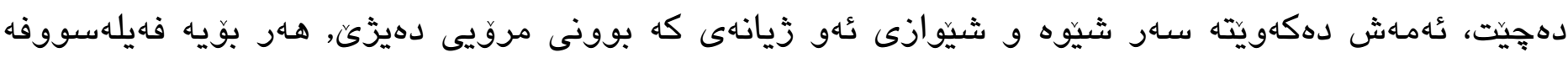


بوونكَراكان دهلِين: ((مروق به ويستى خُوى نهاتوته نيّو بوون، بهلاّم دهتوانيت به ويستى خوّى بوونيتيى

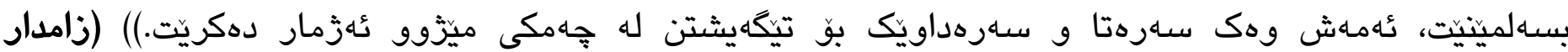
تئحمهد، 2017، ل104)

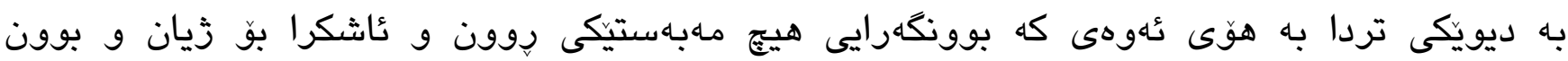
نابينيتهوه, واته ((ذيان هيج مانايهك و ستراكتوريكى زهرووريى نييه. مروث زيان دهكات وهكوو ئينتمايهى

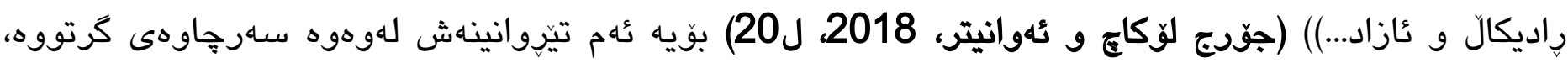

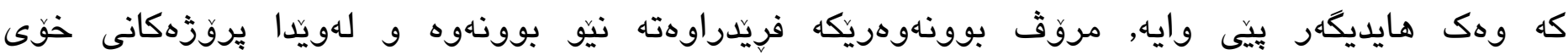
دادهمهزرينيتي. (دهروانريَته: مارتين هايديكهر، 2013، 263)

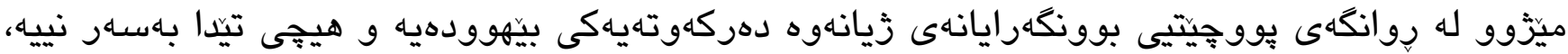

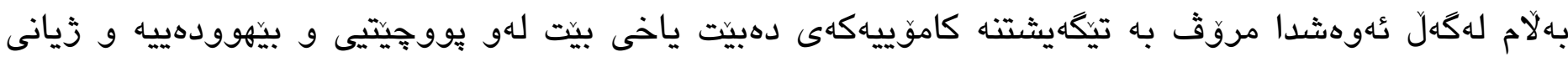

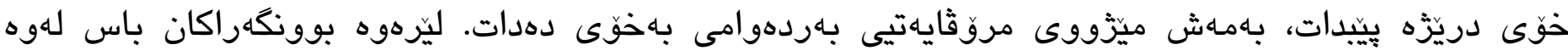

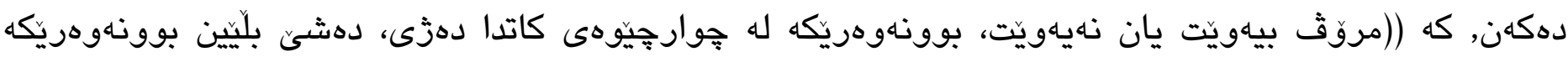
لهكاتدا دهزى ئهكهر هـر نهلِينين ئهو خودى كاته!)((زهكريا ئيبراهيم، 2013، ل122) كهواته مروق وهك بوون ((سهر به كاتيتيى بوون به كثتييه و... راستهقينهيهكى له كات بهدهر نييه.)) (محهمهد كهمال، 2014، ل179).

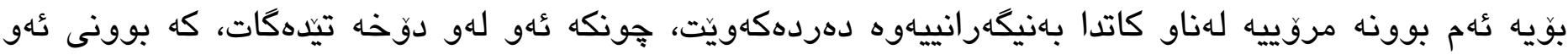

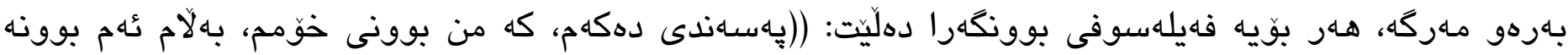

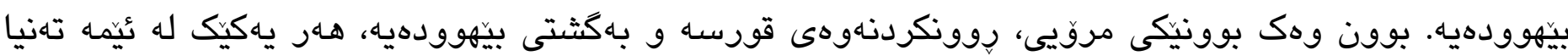

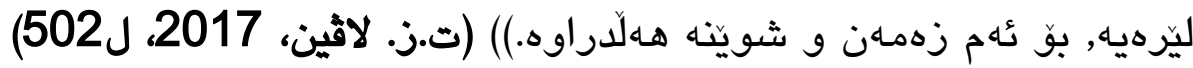

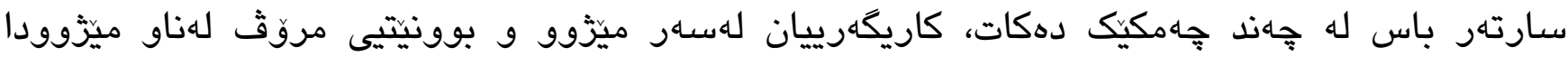

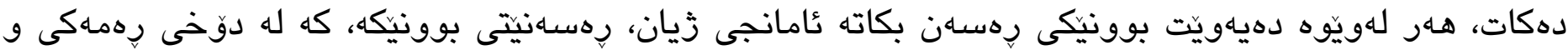

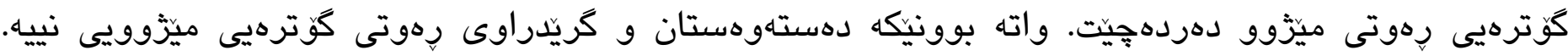

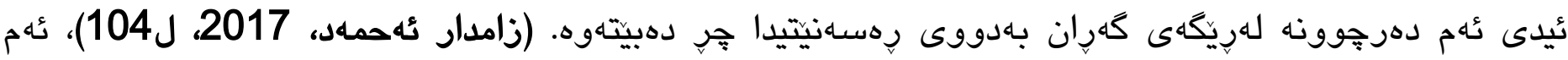

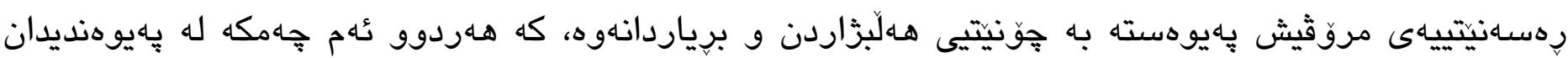

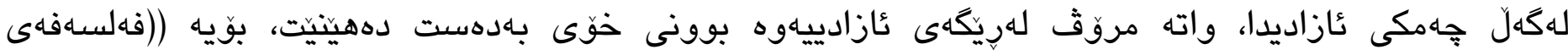

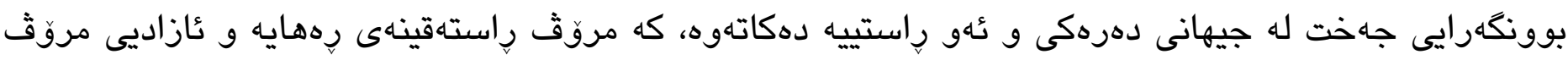
بهنده به بوونى خودى خَى لهجيهانيكدا، كه به نهزاندراو و ليَّل وهسفى كردووه و مروّ كَمارق دهدات لهو

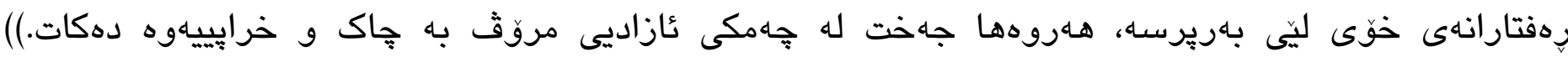

(موفيد ئهلزهيدى، 2015، ل32) 
لهكوى تئوهى لهروانكاهى فهلسهفهى بوونكاراييهوه خرايه روو، دهردهكهويت لهوهى ئيماهى مروق

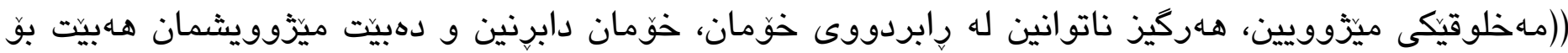

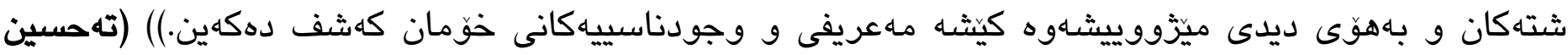
حهمهغريب، 2013، ل61- 62). بوونى مروق نئوهيه، كه هـيه و لهكاتدا خوّى دهردهخات، هـرجى ماهييهتى

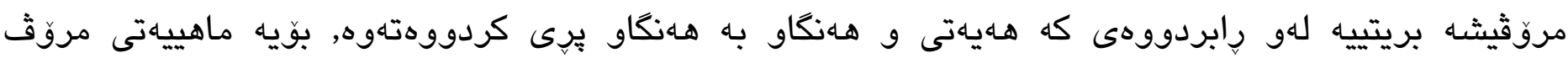
دوخيّكى داخراوه, تا ئهو جركهاتهاتى كه مروق وهك بوون لهناو ميّزّووى جيهاندا دهردهكويّت.

\section{بلإُى دووهم

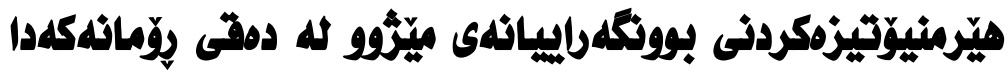

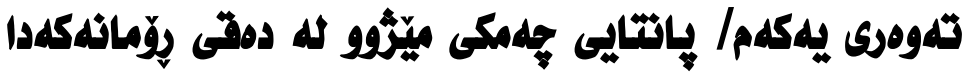

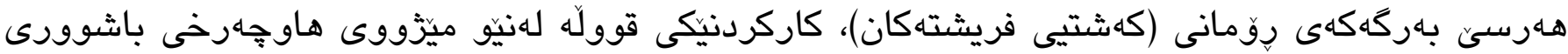

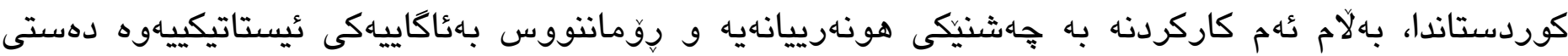

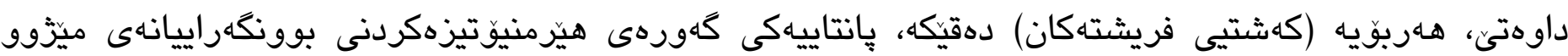

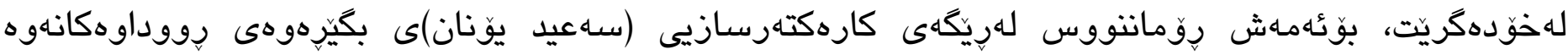

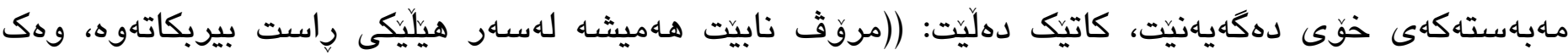
كُهوهى زيان و جيهان لهسهر هيلّيكى راست جوولَّبن، كه كوايه ريّيك له رابووردووهوه بهردو داهاتوو

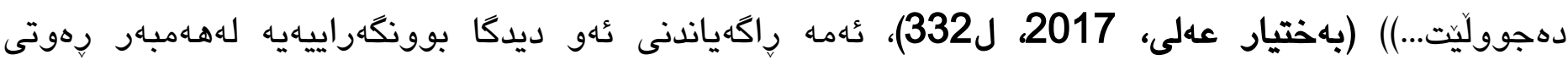

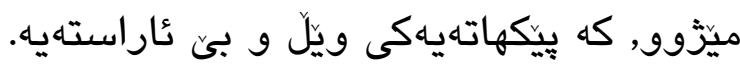

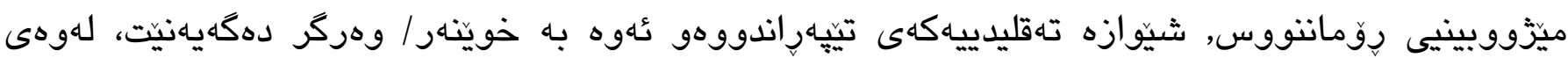

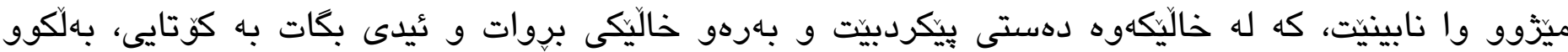
ئهوهتا ئهم دنيابينييه زياتر وهك دوخيك رِوون دهكاتهوهو دهلّيت: ((من جِيم به خهيالّا دههات دهمنووسى،

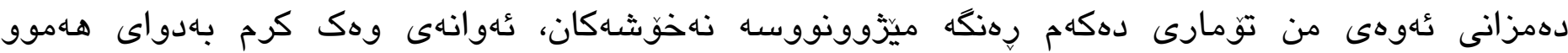

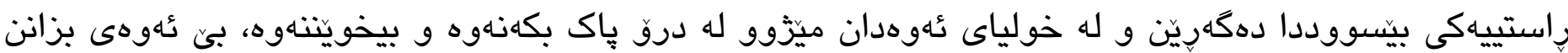

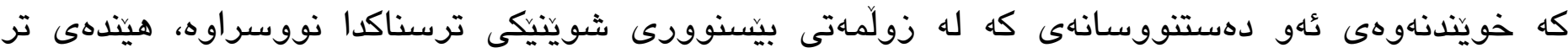
ويلّيان دهكات و له دوودلّى و بِرسياردا ونيان دهكات.)) (بهختيار عهلى، 2017، ل332). بهم شيّوهيه وهركرى

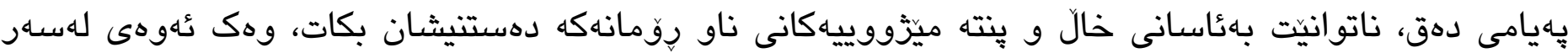

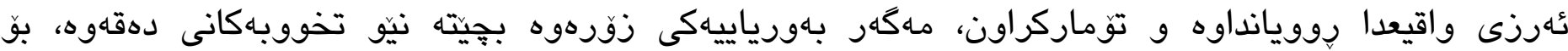




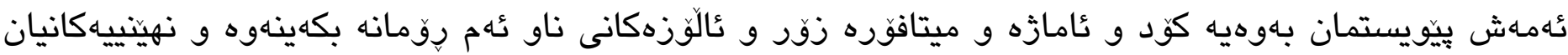

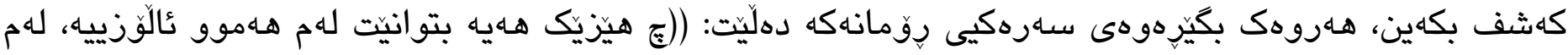
هـموو هيلّه سامناكانهى تييدا خهيال و ميّزوو، جهسته و تارماييهكان، شهيتان و فريشته تيكهلاو بووه،

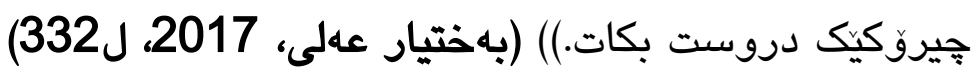

روّمانتووس ئهوه روون دهكاتهوه، كه مامهلّهاهى هونهرى لهكهل ميّزوودا دهكات، واته له زوّر شوينى

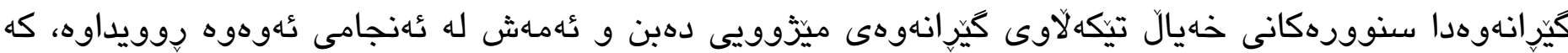

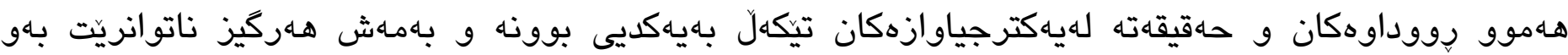

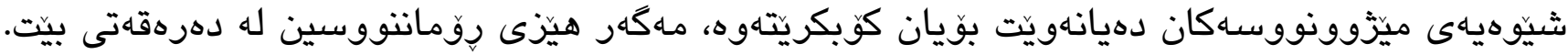

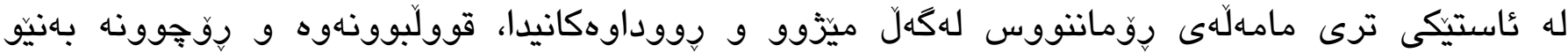

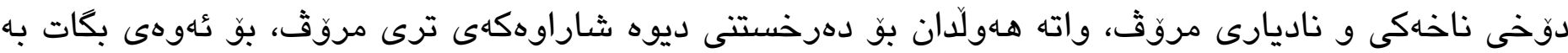

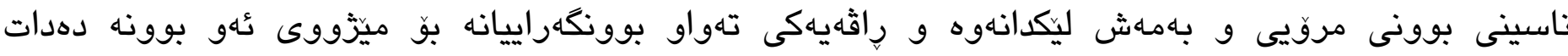

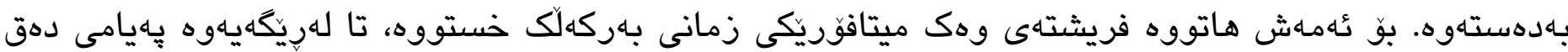

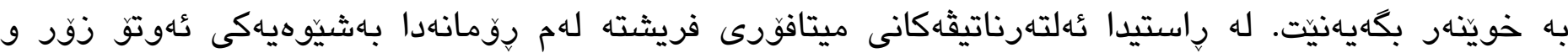

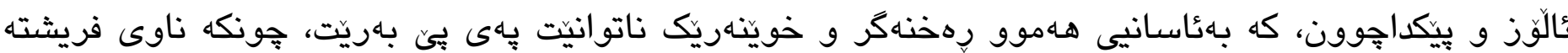
له روّمانهكها له كثان و دريّزبوونهوهيهكى تهواوهتيدايه و جههندين دهلالهتى جياوازى سهاربار كراوه، وهك:

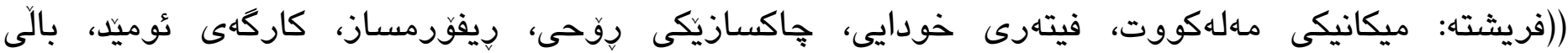
نيوهكوزراو يان خنكاوى خوّ، ورينّهى دهستهاهمى و جִهندين ناوى ديكه...)) دهكريتهوه. (شيّرزاد حهسهن،

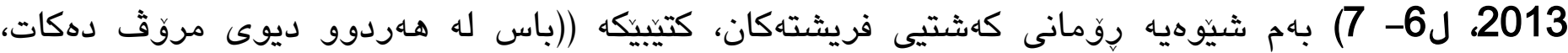
ديويكّى شـرانكيزّ و ئههريمهنانه و ديويكى ميهرهبان و فريشتهئاسا، ديويكى شهيتان و ديويكى رهحمان، ديويكى

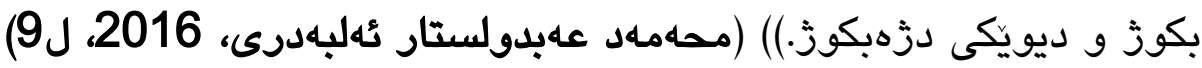

سهاربارى ئهوهى رِومانتووس ميّزووى كردووه به بابهتى رِومانهكهى، بهلاّم له كَلّ ئهوهشدا كارى ئهو له

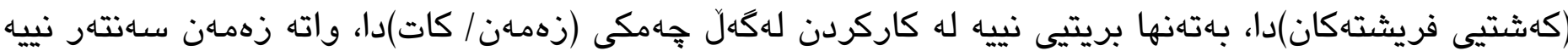

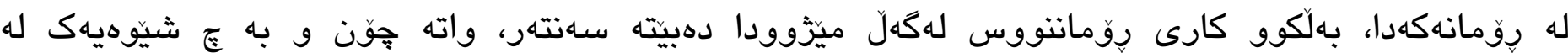

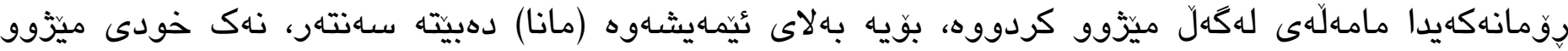

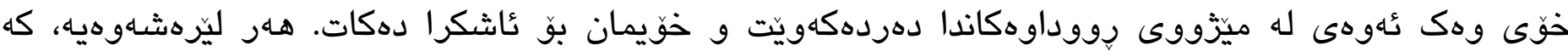

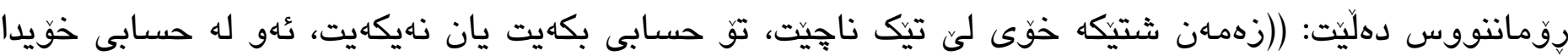

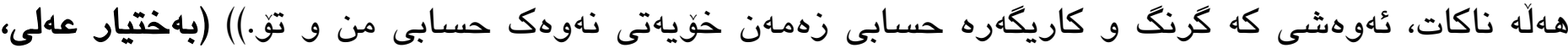

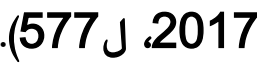




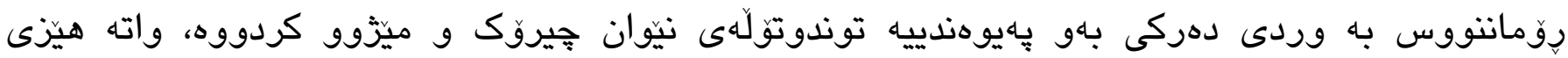

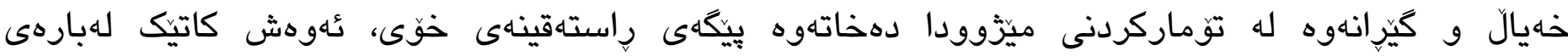

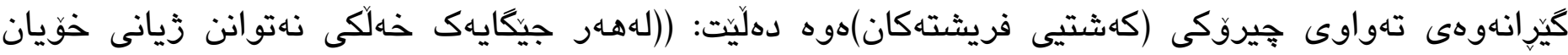

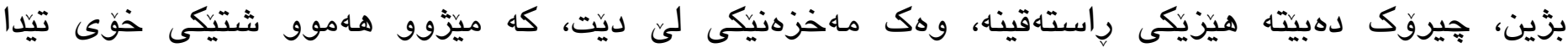

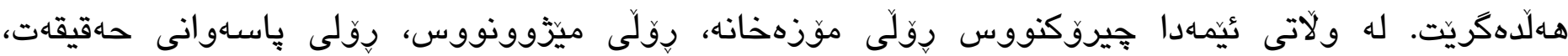

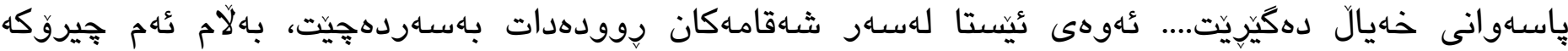

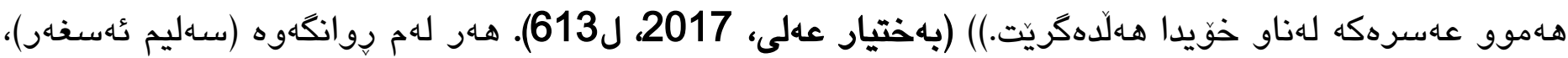
كه بكَيْروهى سـرهكيى رِووداوهكانى ناو رِومانهكهيه و راستهوخٌ دهنكى روّمانتووسى لهيشتهوه ئامادهيه،

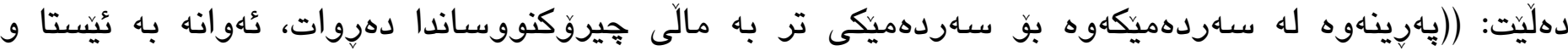

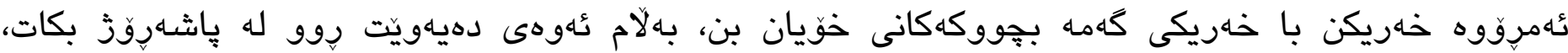

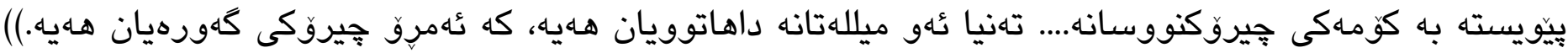

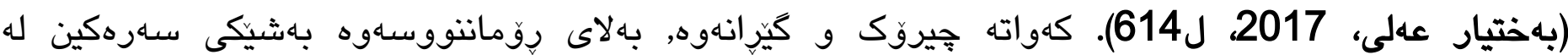

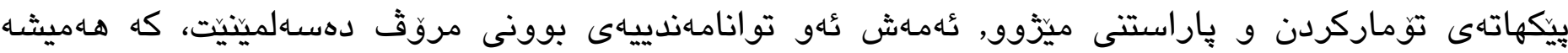
بوونكارايى جهختى لهسهر دهكاتهوه.

\section{تهوهرى دووهم/ بلهديهاتفى مروّق للهناو ميّزوودا:}

مروّق له ديدى بوونكاراييهوه، بوونيكه نههاتووهته دى، واته بوونى مروّق ناكاملّه و لهبهردهواميدايه

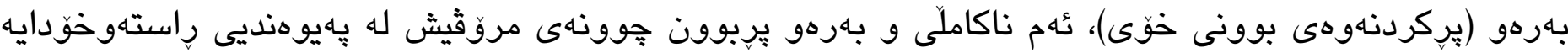

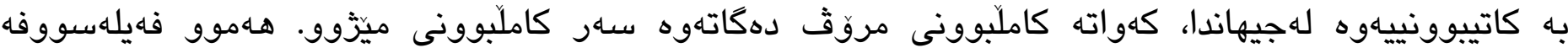

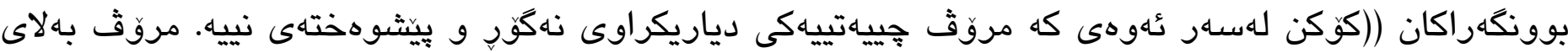

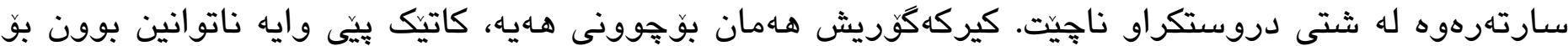

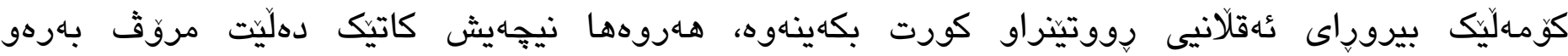
بهرزهمرّق هـاهكاو دهنيت، بهمهاش مروّ لاى هـهوويان ناكامل و ناتهواوه.)) (جون ماكوري، 1982، ص181).

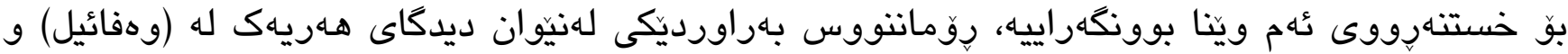
(مهلا مونز)دا كردووه و دنيابينى و تيگَايشتى هـريهك لهو دوو كارهكترهى لهبارهى بوونى مروثهوه خستووهته رِوو، هـروهك دهلّيت: ((لاى مهالا مونزير ئينسان شتيكى جهوهـردار و مانادار و براوه بوو، لایى وهفائيل ئينسان شتيكه هـر نههاتوته دى و بهريّوهيه بو ئهوهى هـهيّت و دروست بيت.)) (بهختيار عهلى، 2017. ل223). بوّيه كاتيك (عهقيد جهنكيز)، (مهلا مونزيرى مهلهككوز) دهستبهسار دهكات و داوا له (هوّشهنى 
بولبوليار)و فريشتهكان دهكات، تولّهى خوّيان به كوشتن بكهينهوه، يهكيك له فريشتهكان كه ناوى (وهفائيل)ه، دهلّيت: ((عهقيدى ئازيز، من بهشيك له تو بووم و كيّيستا لهم دونيايهدا وهك روحيَكى غهريب و سهرليشيّواو

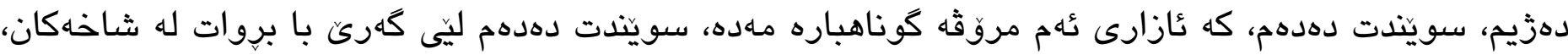

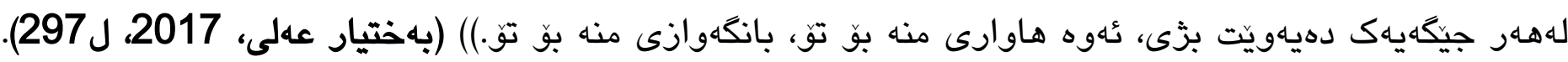

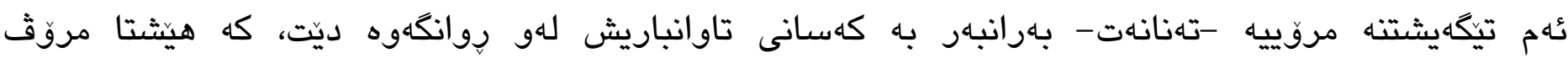

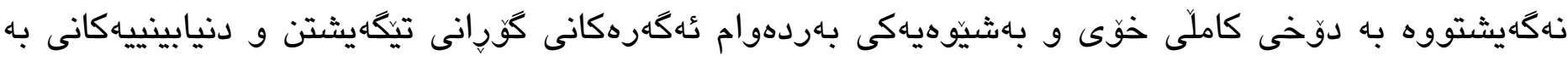

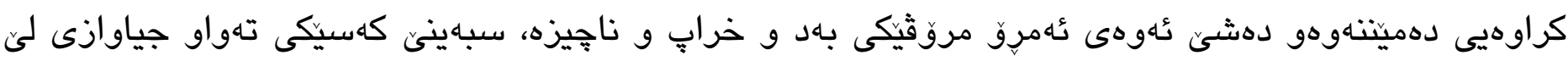

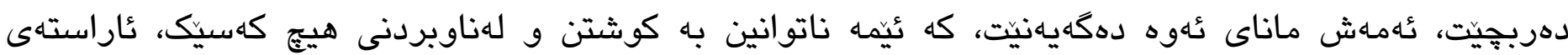

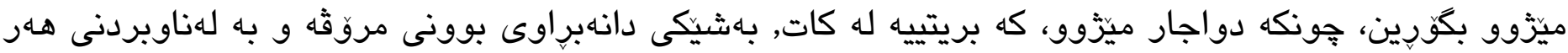

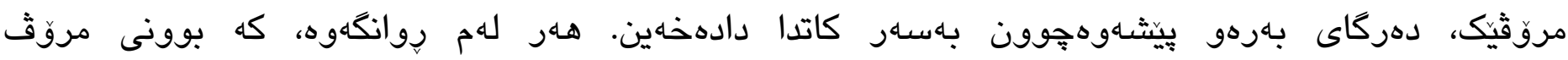

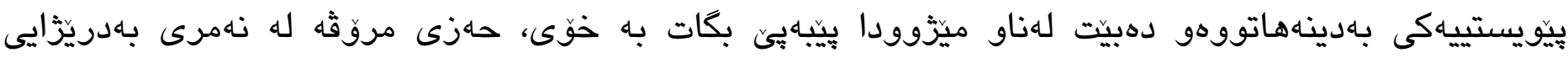

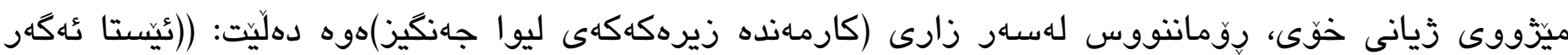

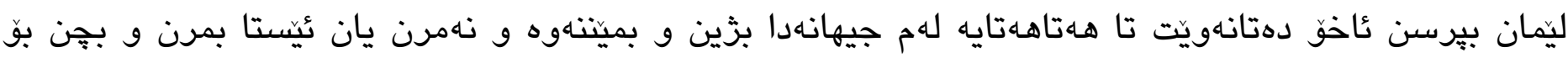

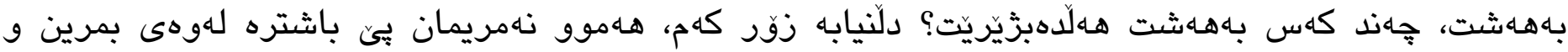

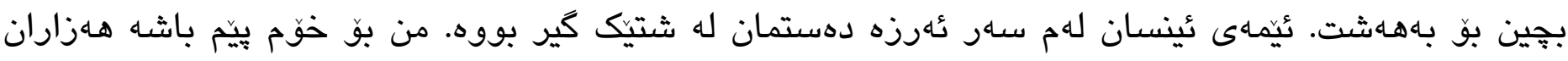

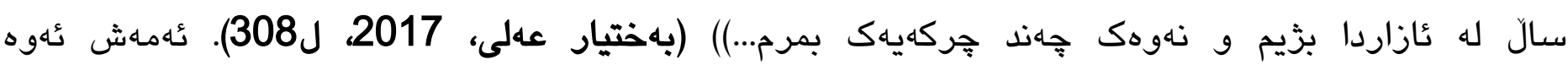

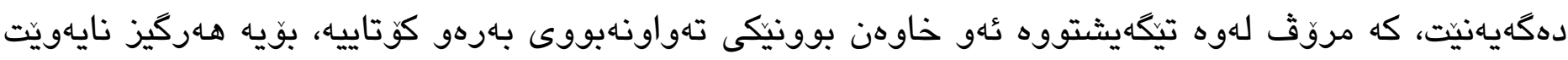

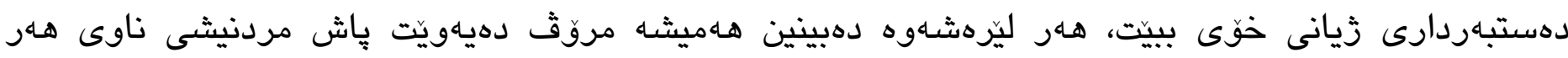

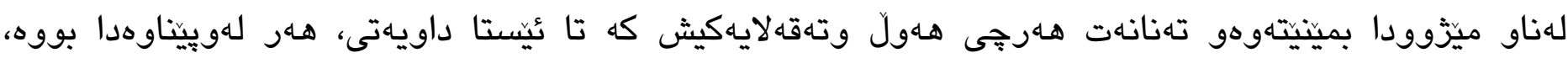

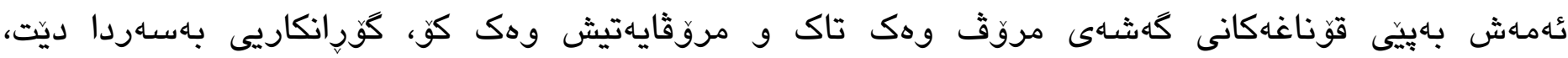
هـروهك كارمهنده زيرهكهكهى ليوا ديسانهوه دهليّت: ((من لهو كهسانهم كه باوهرم بهوهيه مروق له حهيوانهوه

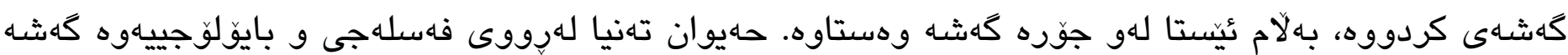

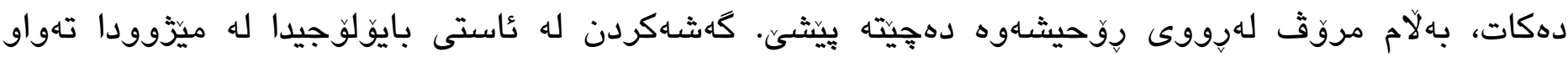

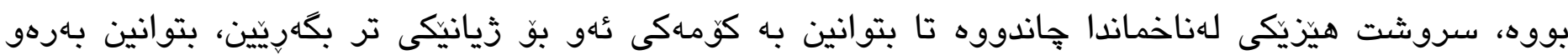
شتيكى باشتر له خوّمان سـركهوين و يُهرهبستينين...)) (بهختيار عهلى، 2017، ل309)

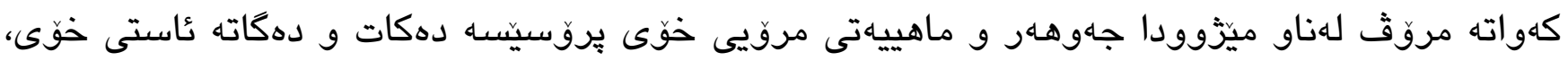

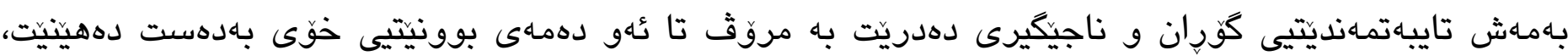

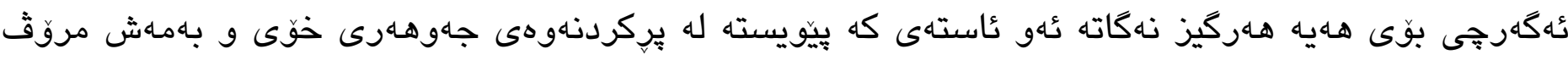
له ئاستى بوونى نارهسهندا (به واتا هايديكهرييهكهى) دهمينيتهوه، هـروهك رِومانتووس له خستنهرووى ديدى يهكيك له كارهكتهرهكانى ناو رِومانهكهى، كه ناوى (دكتور نهزمى)يه، دهلّيت: ((جهوهـهى ئينسان نئه شته ونهيه، 
كه نايكاتي، مروق ثئو شته نييه كه هـيه، بهلكوو ثئو شتهيه كه نابيت و نهبووه و نايهتهدى. جياوازيى نيّوان

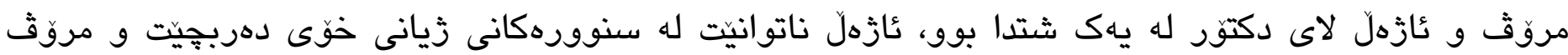

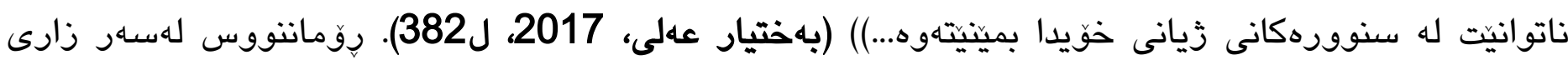

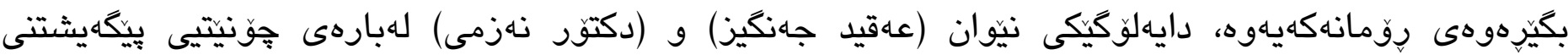

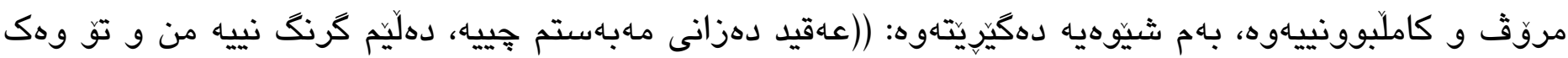

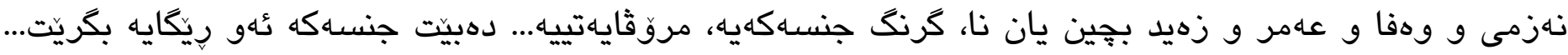

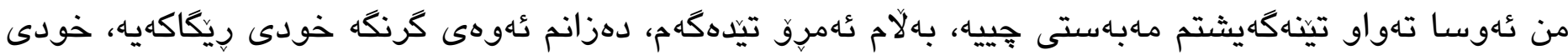

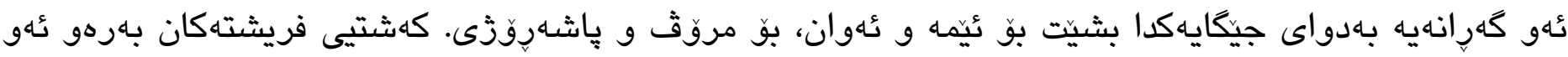
جيكّايه دهرويشت، بهرهو عُهو كيشوهره، ئهو دووركهيه، ئهو سهرزهمينه نهدوزراوهيه.)) (بهختيار عهلى، 2017.

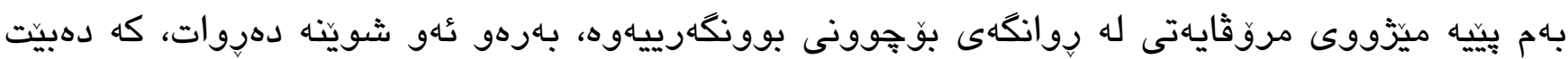

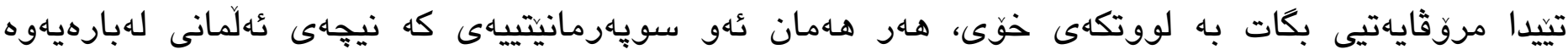

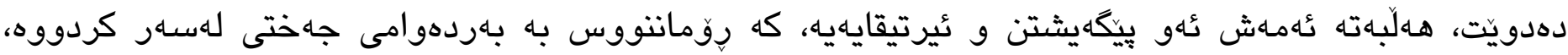

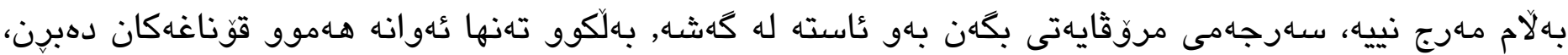
كه وهك بوونى رهسـن دهردهكهن و دواجاريش بـرزهمروث (سويهرمان)ى نيجههيانه. لهلايهكى ترهوه و

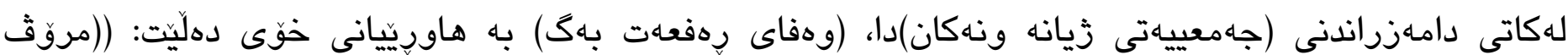

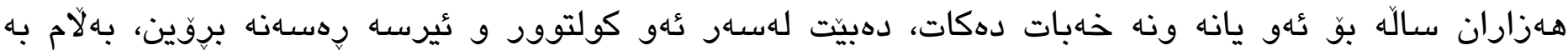

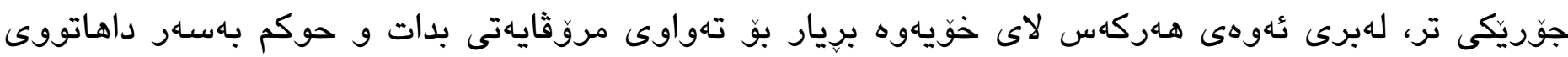

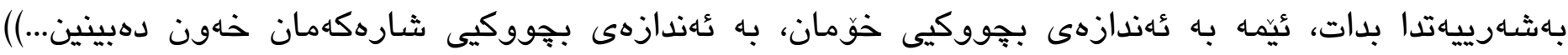
(بهختيار عهلى، 2017، ل491). كهواته بهشيكى تر له بهردهواميدان به سوورانهوهى ميّزوو، بريتييه لهو خهون و خوليايانهى كه مروّق له زيانى خَّيدا هـيهتى و هـول بو بهديهاتتيان دهدات، هـر عُهمه ش وا دهكات لهوهى

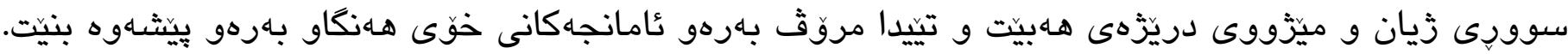




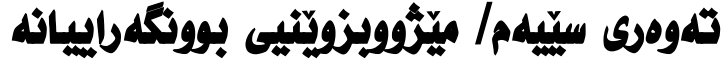

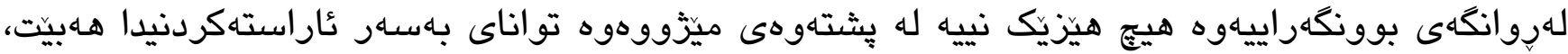

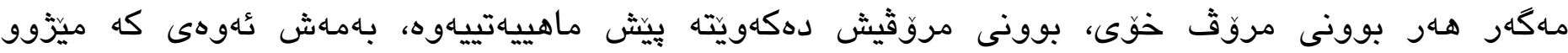

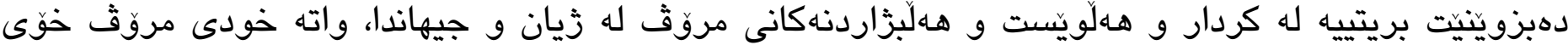
عاراستهكهرى ميَزووه و هاوكات لهناو ميَزوويشدايه. به مانايهكى تر ئازادى و ياخيبوون ئهو دوو هيَزه

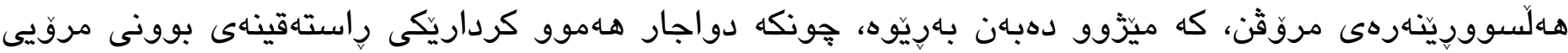
رهسـان، وابهستهيه به ئازادييهوه، لهوهدا ئهكَر مروقيك ئازاد نهبيت، هيزّيشى بهسهر هيتج رووداويكدا ناشكيت و كيرادهى دهبيتهوه به سفر، هـروهها وابهستهيشه به ياخيبوونهوه لهوهدا، كه كاتيك مروق ثازاديى لئ دهستيندريتّهوه، بهرهو كويلهبوون دهروات و بهمهاش دهبيت دهست بو ياخيبوون بهريت، دز بهو دهسهلاتهى

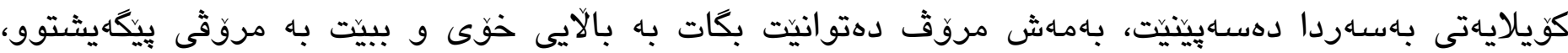

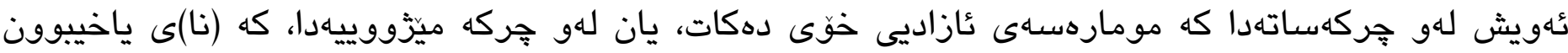

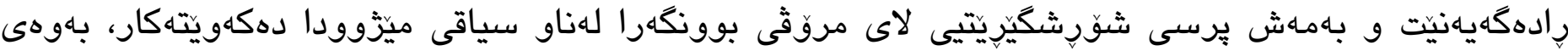

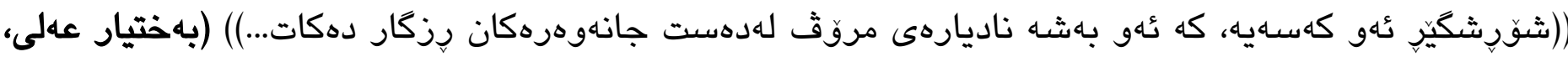

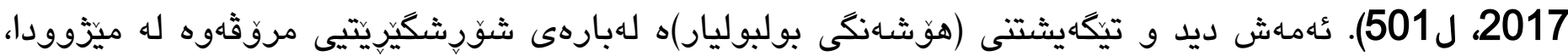

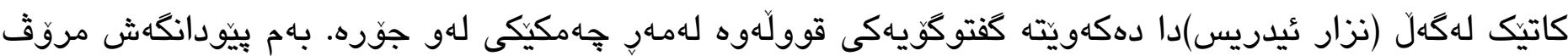

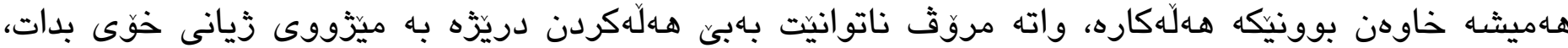

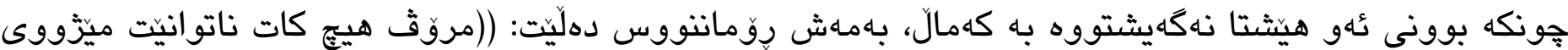

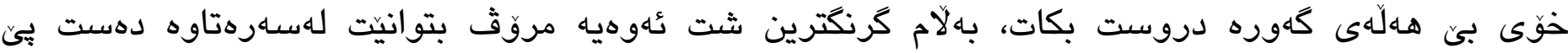

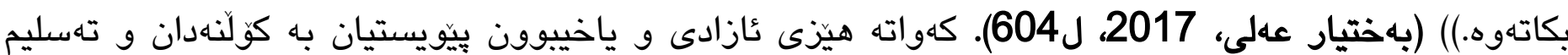

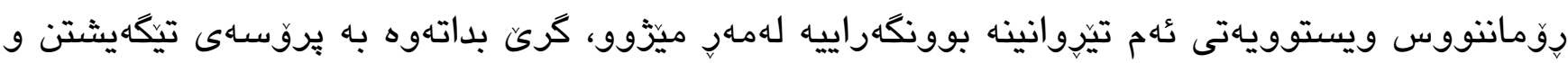

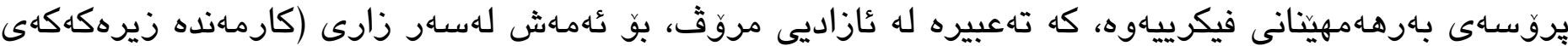

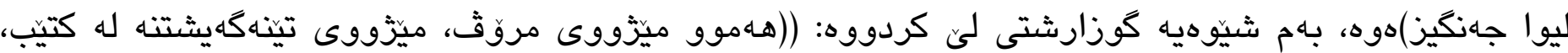
لهوه زياتر هيج شتيكى تر نييه، ئهوهى تا تيّستا ميزّووى جوولآندووه، ململانيىى جينايهتى يان غهريزه جنسييهكانمان نين، بهلكوو ئهو جاهيلانهن كه به هـله كتينبهكانيان تهفسير كردووه، ئهو جاهيلانهن، كه ماركس و داروين و فرويديان به هـلّه تهنسير كردووه.)) (بهختيار عهلى، 2017، ل359).

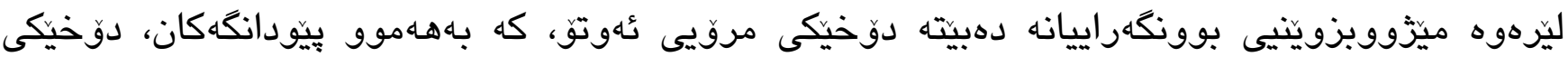

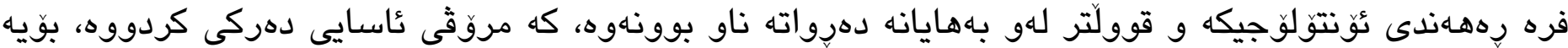

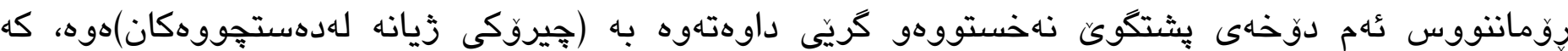




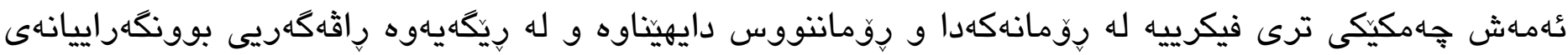

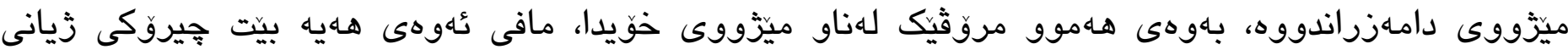

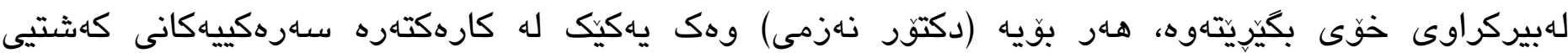

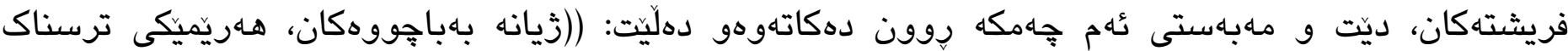

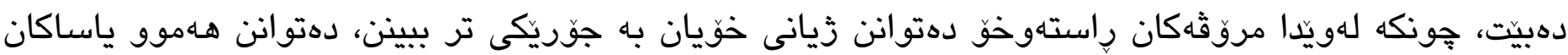

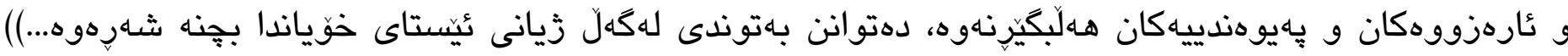

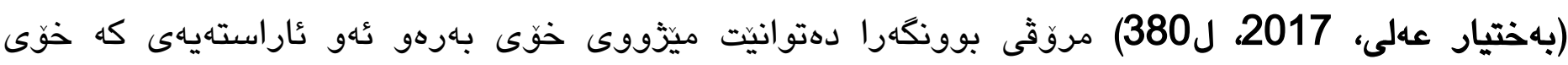

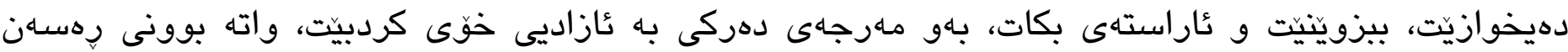

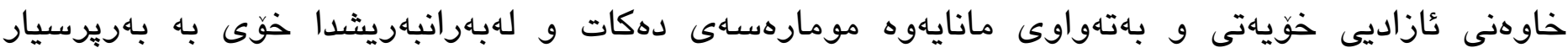

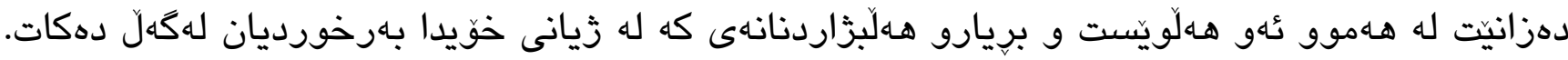

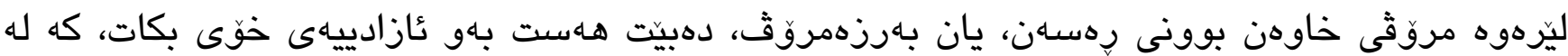

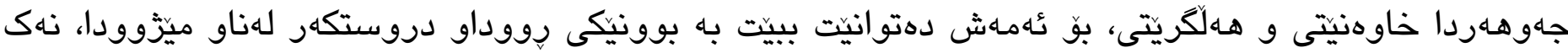

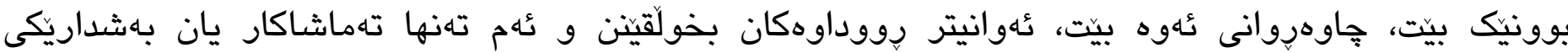

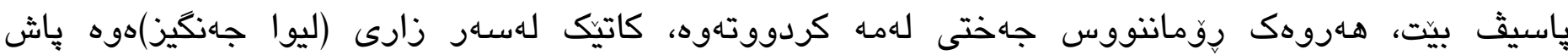
دهرجوونى له زيندانى حيزب دهلّيت: ((بهشى هـره زوّىى مروّثهان مهذلوقى رِووداو دروستكهر نين، بهلّكوو

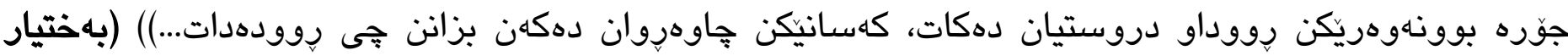

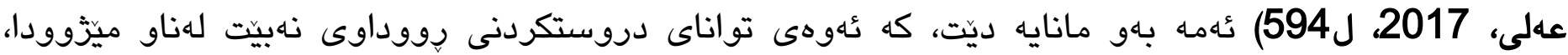

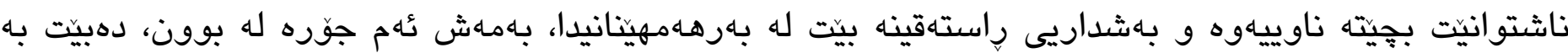
جوّره كويلهيهك له تهرزيكى جياواز، كه هـركيز ناتوانيت بهبئ ئهويتر هـنكاويكَ له زيانى خوّيدا بنيت، ههروهك

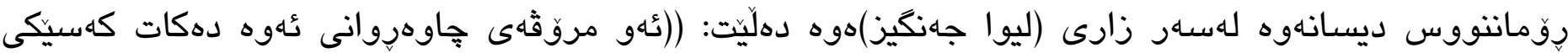

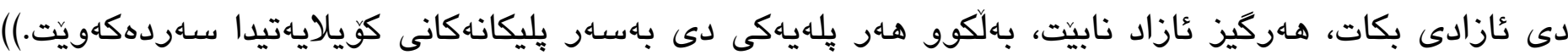

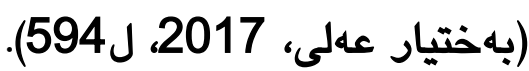

بهم شيّوهيهش ميزّووبزوينيى بوونكهرايانه له بهيوهنديدايه لهكهل جهمكى (كهرانهوهى هـميشهيى) لاى نيجه (بو زانياريى زياتر، برِوانه: (أ)مستهفا غالب، 2008، ل45ه ههروهها: (ب)محهمهد كهمال، 2006، ل207)

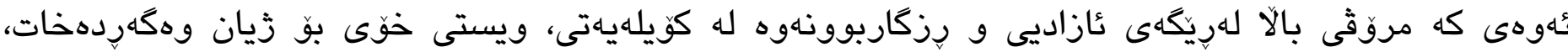

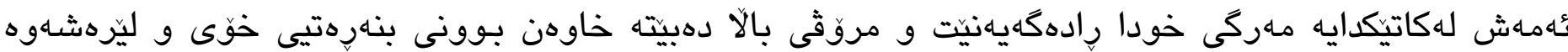

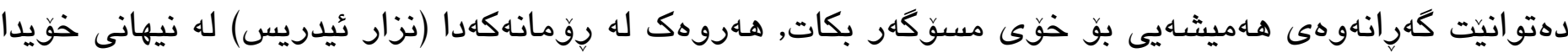
ئهوه روون دهكاتهوه، كه ((كوتايى هيجيج نييه جكه له دووبارهبوونهوهيهكى ترازيديى و خويناويى سهارهتا. هاهوو

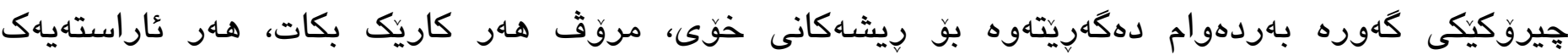




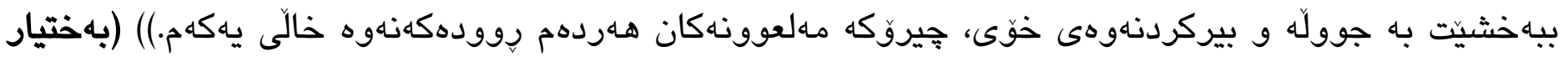

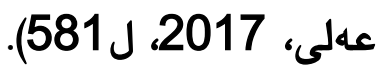

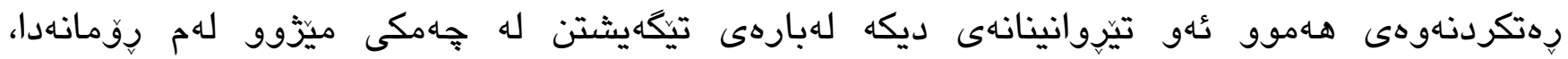

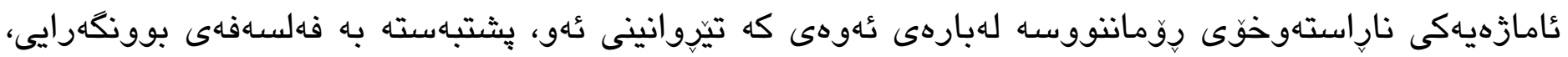

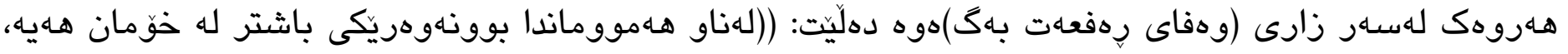

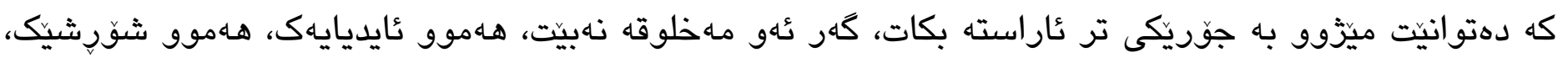

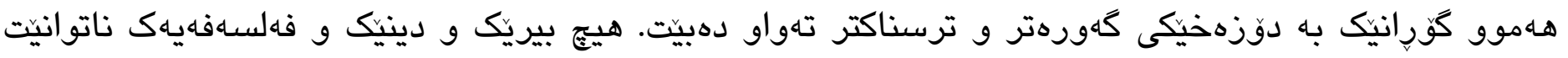

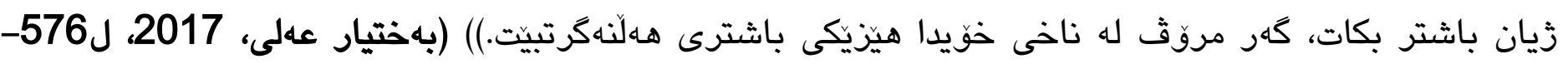

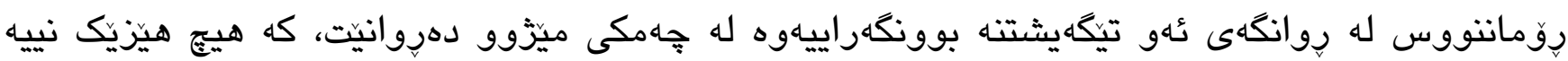

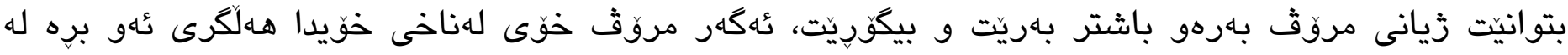

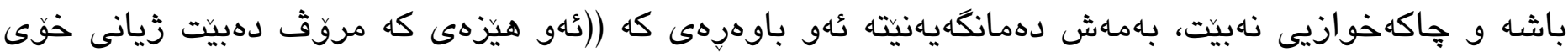

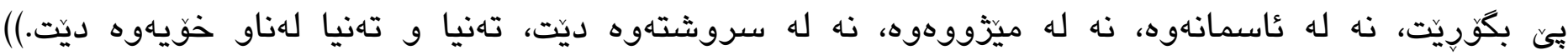

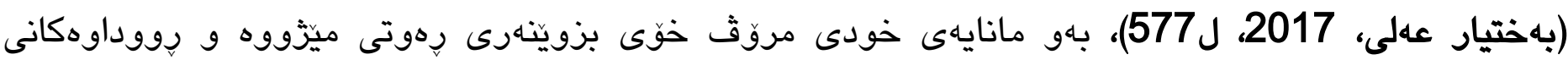

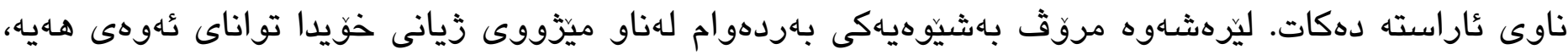

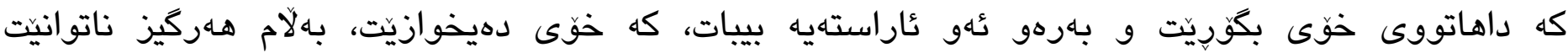

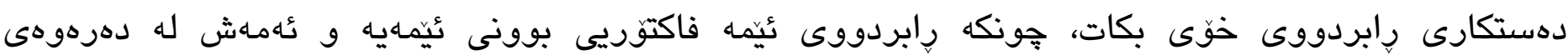

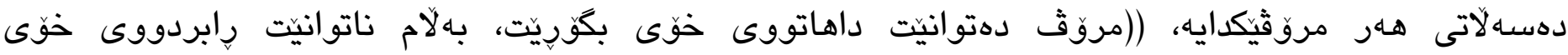
دهستكاريى بكات، دهستكاريكردنى رابردوو له مهاله كاورهكانه، كه هيج كات ناتوانين بازى بهسهردا بدهين.)|

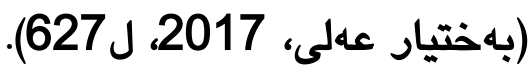

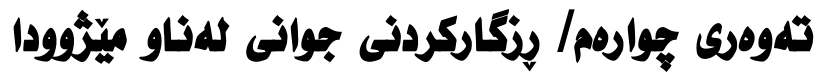

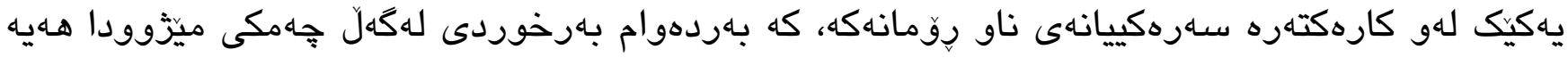

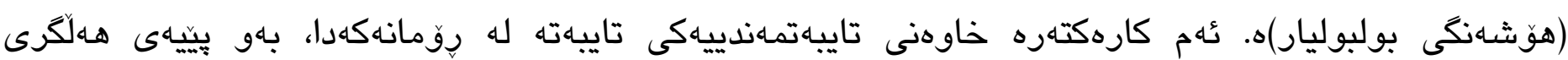

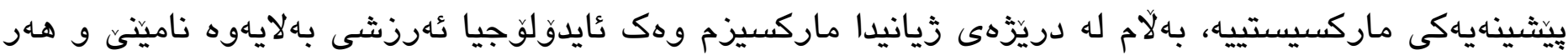

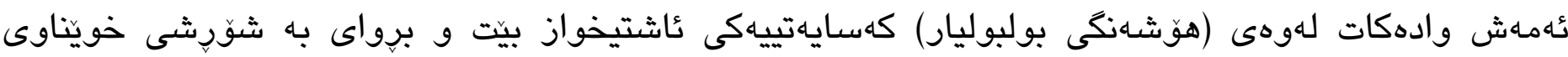




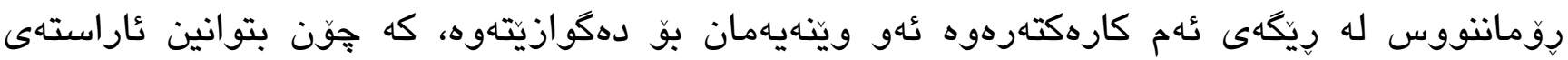

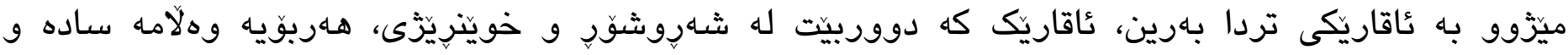
ئاسانهان بولبوليار قايل ناكهن بهوهى باوهر به دروشمه حازربهدهستهكان بهينيتي، وهك عُهوهى كه (بهدهربرينى

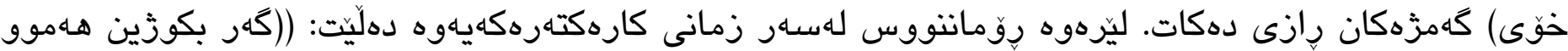

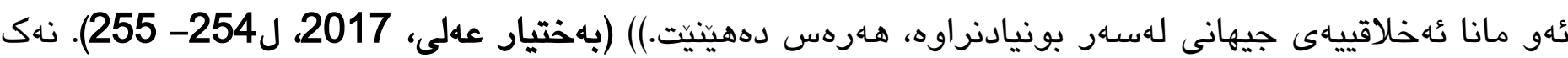
هـار ئهوهنده، بهلكوو رِومانتووس توانيويهتى ئهم ديده وجودييه تهواوتر بنوينيتيت و بهمهاش دهلِيت: (لههـر

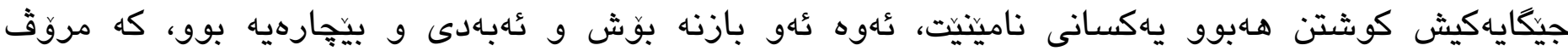

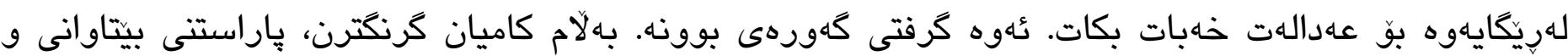
ياكيى مروّق، يان دروستكردنى عهدالهت؟)(بهختيار عهلى، 2017، ل137). تُهوهى كه زياتر ئهم تيّروانينه بوونكاراييه زهق دهكاتهوه، عُهو ديالوَكَى نيّوان بولبولياره، كاتيّك له وهلامى (دكتور نهزمى)دا دهلِّت: ((مروق

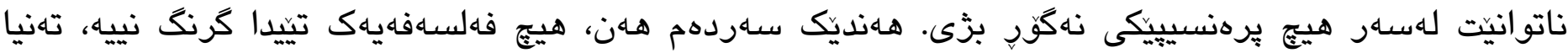

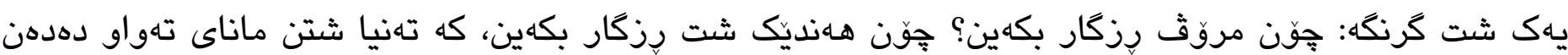
به بوون، جِون دهتوانين شتيك بكهين، نهبين به بهشيك له دابهشبوونهكان، نهبين به بكهرى ناراستهوخوى

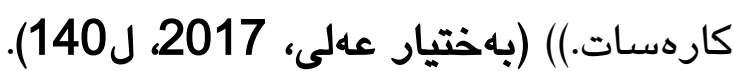

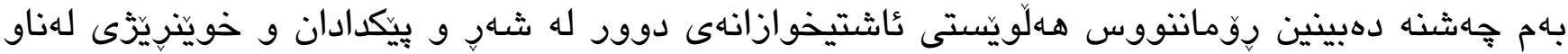

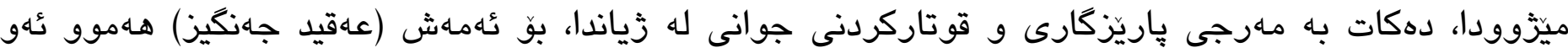
ميّزووه رهات دهكاتهوه، كه لهسهر بنهاماى خويَن بونيادنراوه و دهلّيت: ((مروقّكان وا راهاتوون، كه تهنيا له

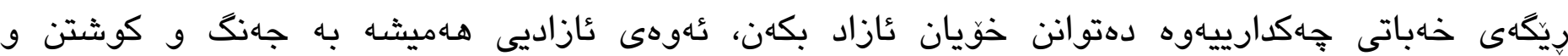
ويّرانكارييهوه كريّدراوه، بهشيكى هـميشهيى ميّزووى مروق بووه...)) (بهختيار عهلى، 2017، ل492)، ئهم

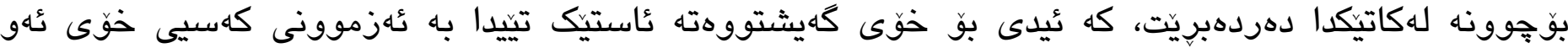
باوهرهى داهيناوه و لهكَل هاوريِيانى كهشتى و جهمعييهتى زيانه ونهكاندا هـول دهدات بيكات به بهشيك له زيان و بوونى خويان و تهنانهت كاريش بوّ عُهوه دهكات، كه ئهم جوره له تيزّى زياندوستى بكات به كلتوور.

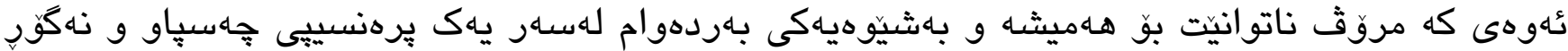

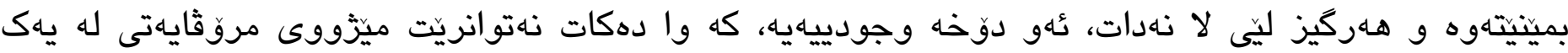

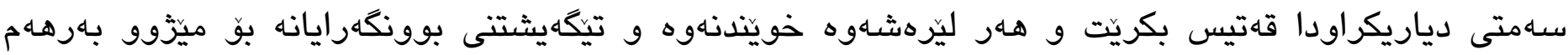

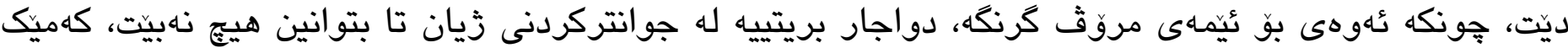

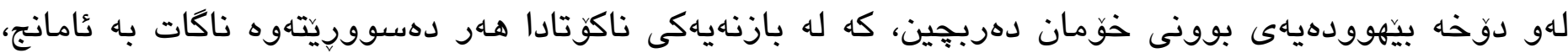

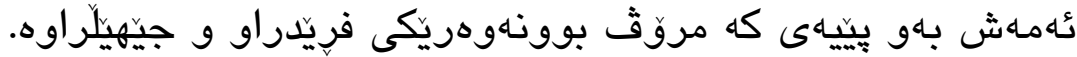




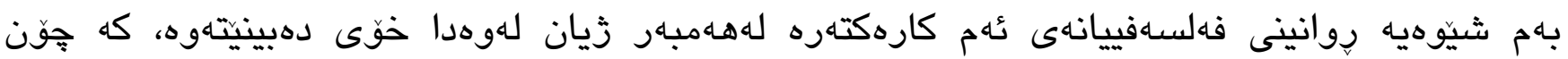

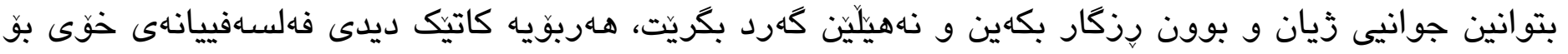

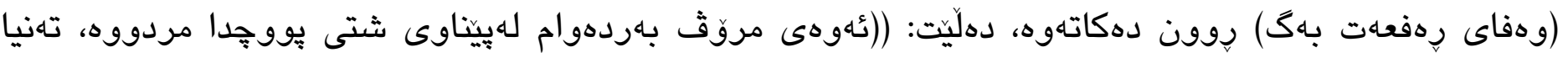

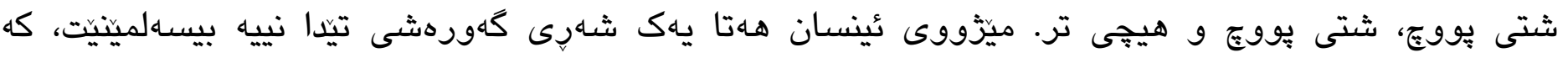
مروّق له جهنكاكاندا بوّ شتى كرنك جهنگيوه.)) (بهختيار عهلى، 2017، ل182).

له فهلسهاهى بوونكَراييدا تُهوهى كه كرنكه و لهيّيشهاوهى هـهوو شتيكهوه دادهنريّت، بوونى مروّييه وهك دهركهوتهيهكى بوونه كثتييهكه، هـر بوّيه ميّزوو لاى بوونكاراكان بريتييه لهو ميزّووهى كه ثيهم بوونه مروييه لهناويدا دهزيت، بوّيه ئهوهى بتوانيت مانايهك بهو ميّزووه زياوهى بوونى مروّيى بدات، تهنها خوّى

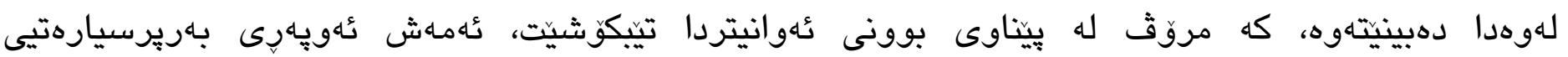

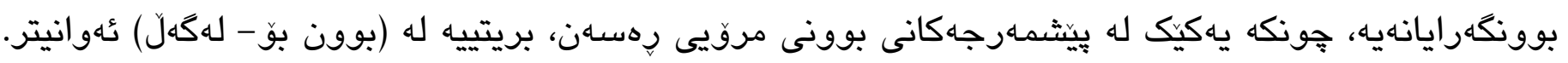

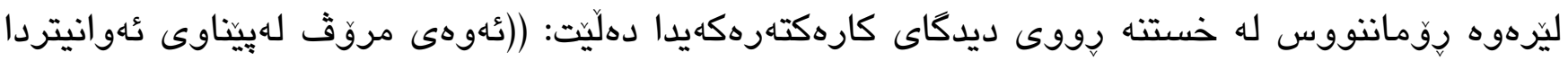
بمريّت يان عازار بكيشيت، بوونى خوّى بخاته تههلوكهوه، شتيك بوو لاى ئهو له رهنجى ئينسان به دواى نان و سامان يان بهختهوهريدا سروشتيتر بوو. كهمزهيى كهورهى هـهوومانى لهوهدا دهبينى، كه دهتوانين لهينيناوى

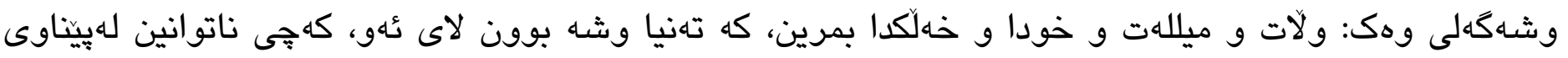

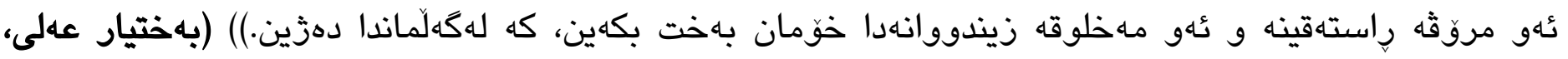
2017، ل182). هـر بوّيه دهبينين ترس و نيكُهرانييهكانى (هوّشهنكى بولبوليار) لهوهى كه نهتوانيت جوانييهكانى

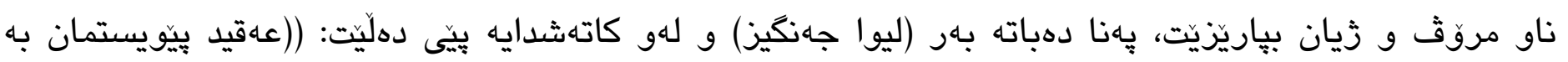

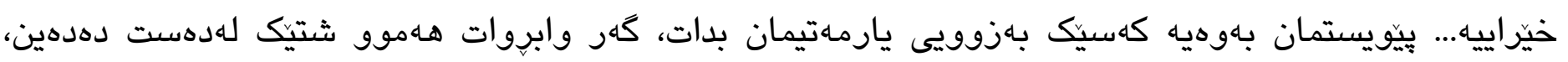

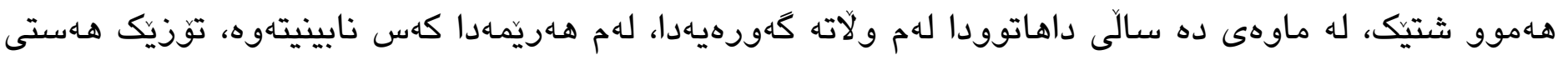

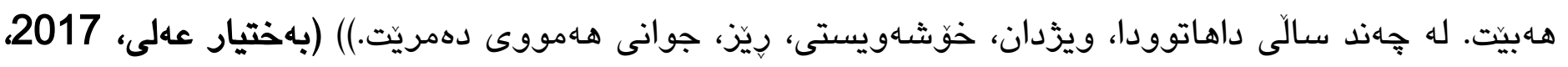

ثاهم ترسه بوونكاراييه له مـركى هـموو شتيك، ترسه لهو عايندهيهى كه مروق بهرهو رووىى هـنكاو

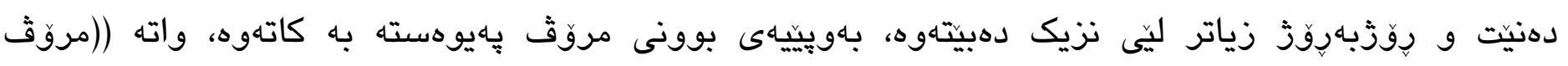

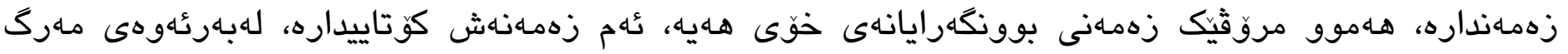

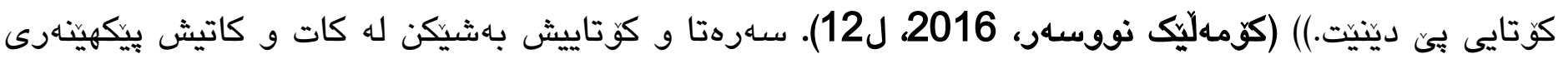

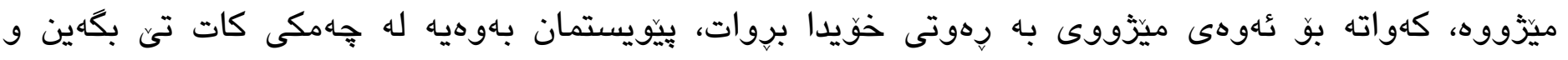
كُهمهش وامان لئ دهكات، بزانين به ع شيّوهيهك وهك بوونيكى رهسـان دهجينه ناو ميّزووهوه. هـهر بهم

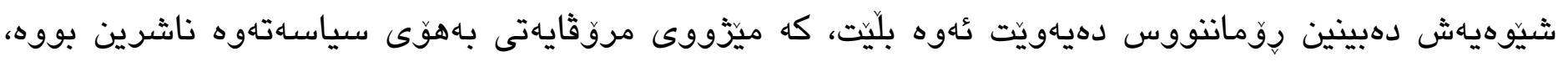

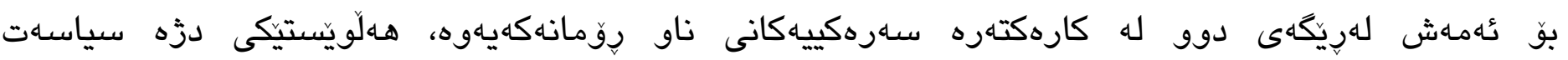




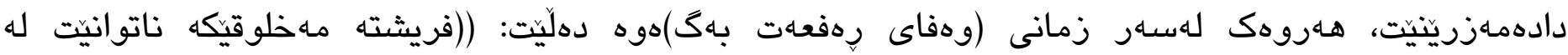
سياسهت تئ بكات، هـر تئوهشه دهيكات به فريشته، هـركهس باش له سياسهت تيكايشت، دلّيابن له

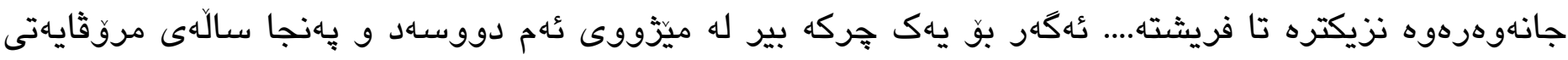
بكهن، دهزانن خرايترين جانهوهرهكانى دونيا ئهوانه بوون، كه باش له سياسهات تيكّاهيتوون.)) (بهختيار عهلى،

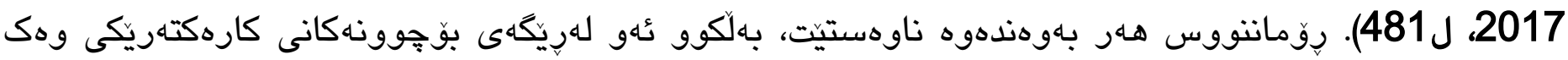

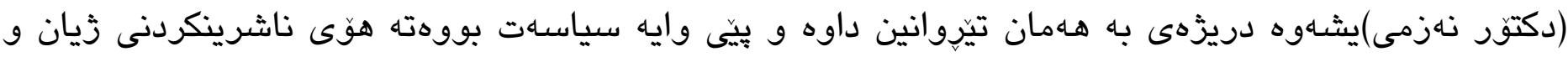

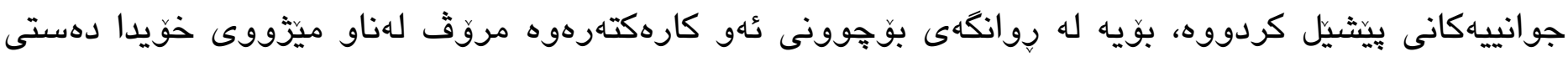

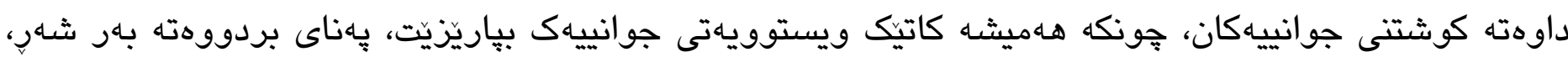

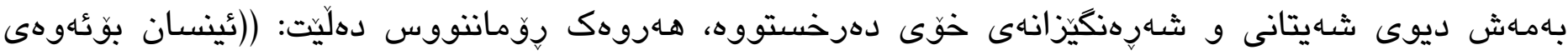

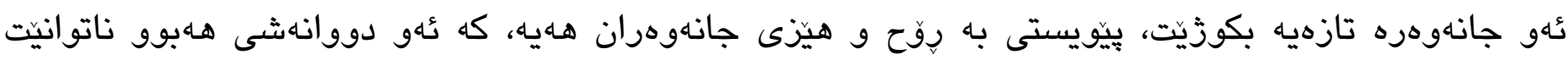
بييتهوه به مروق، ئيدى خوّيشى بووه به جانهوهر، ئهوه ئهو بازنه شهيتانى و داخراوهيه لهناويدا كيرمان

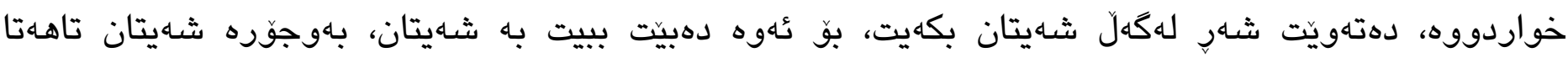
هـاتايه خوّى بـرهـهم دههينيتهوه...() (بهختيار عهلى، 2017، ل 427). 


\section{كلهزجمامكاز}

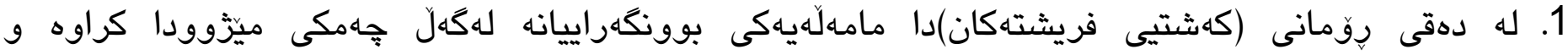

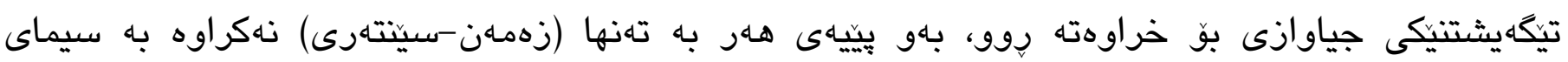

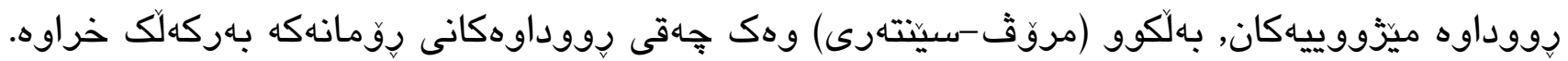

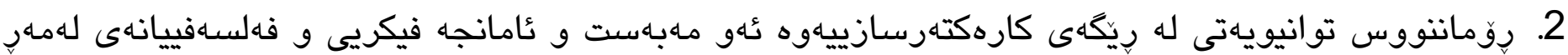
ميّزّوو ههيهتى، بخاتهروو، واته توانيويهتى ميزّوو وهك بابهتيكى هونهارى تهوزيف بكات، نهك وهك ئهوهى

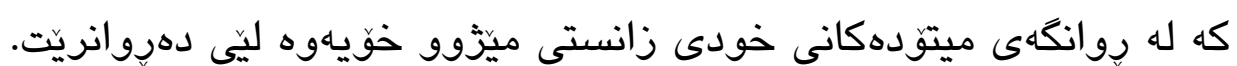

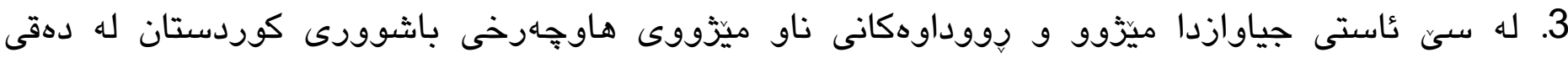

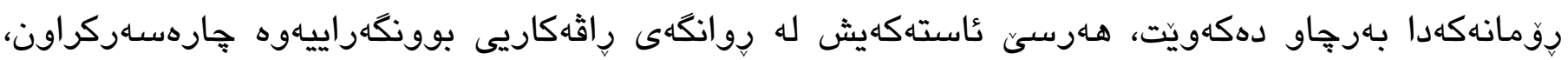

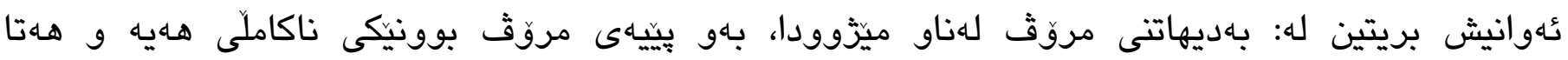

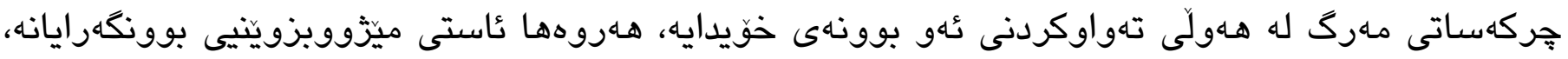

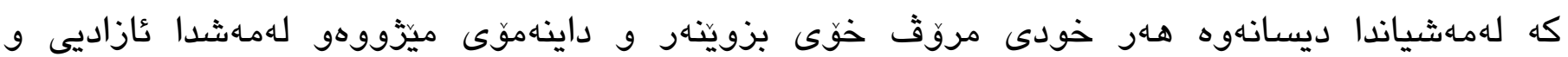

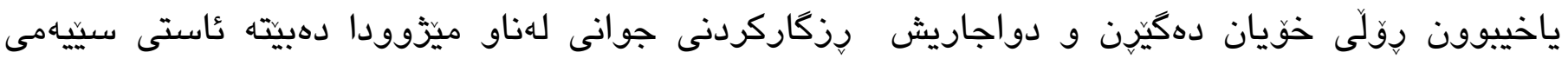
هيّرمنيوتيزهكردنى بوونكهرايانهى ميَزْوو له دهقى رِوّمانهكهدا. 


\title{
ليستى سلهجاوهكاز
}

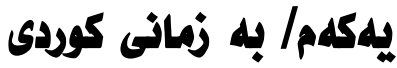

\author{
(أ)
}

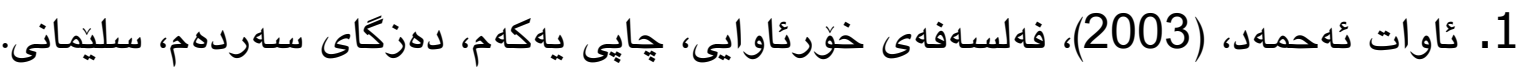

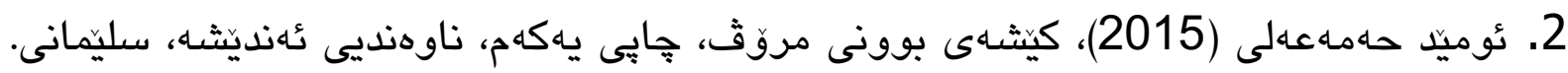

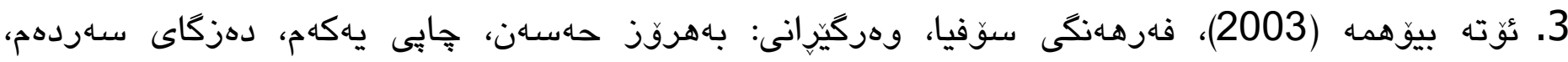

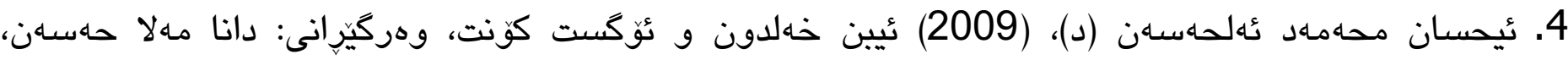

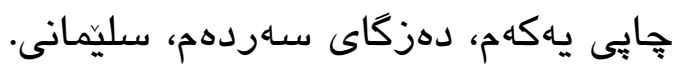

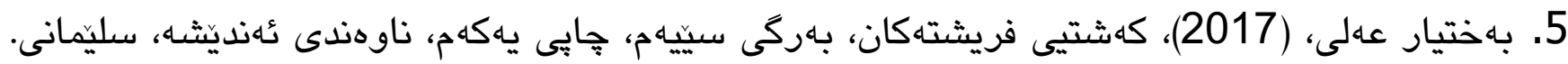

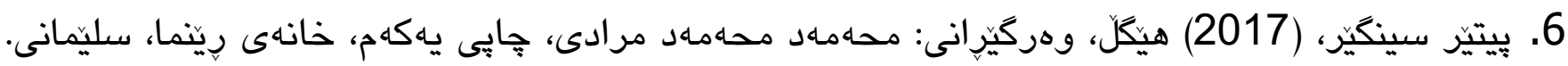

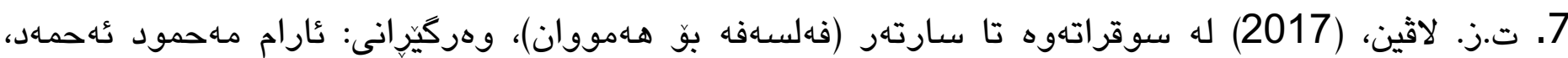

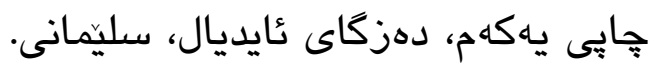

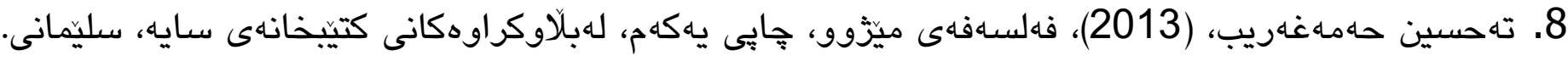

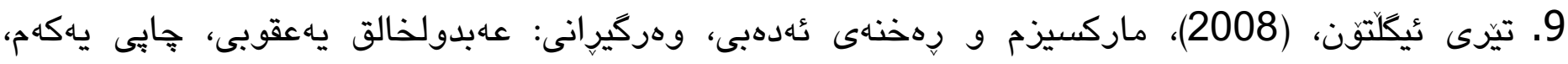
دهزكاى تُاراس، هـهوليَّر. 10.

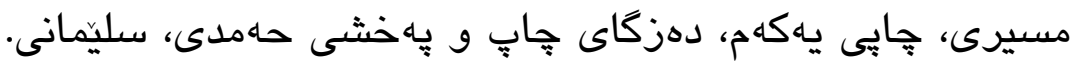

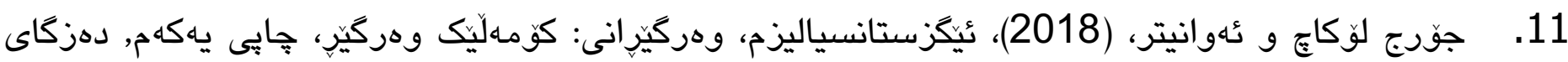
نايديا, سليمانى.

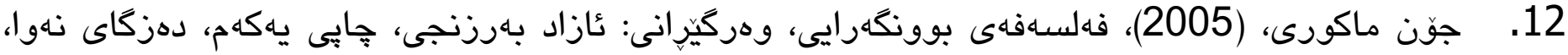
سلينمانى.

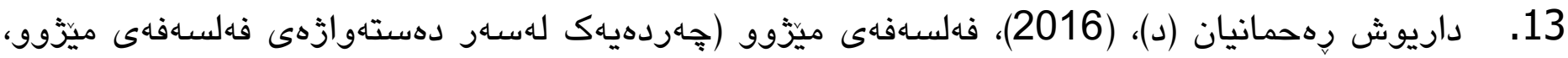

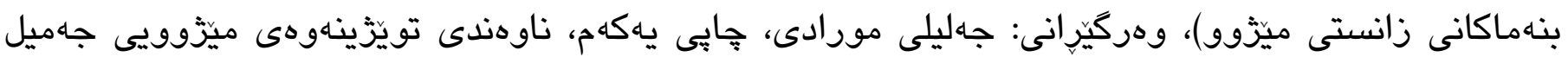
رِوّبهايانى، سليّمانى.

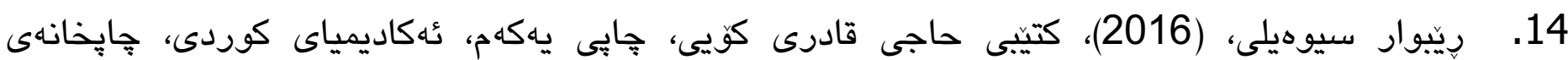

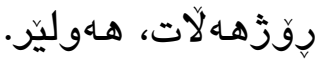

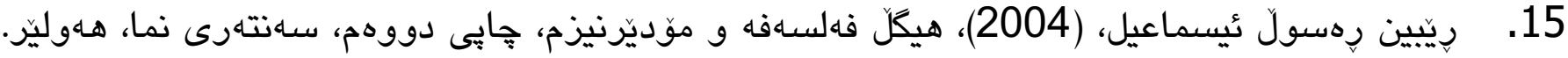

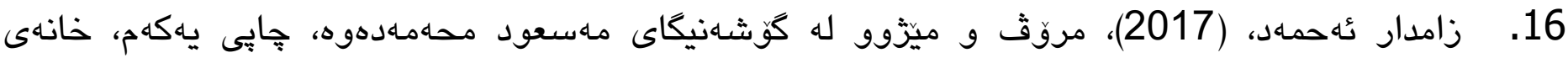
جָوارجّرا، سليّمانى.

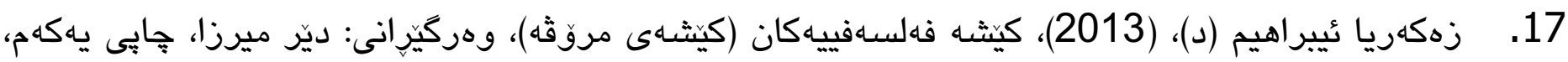

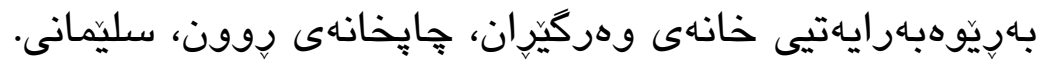




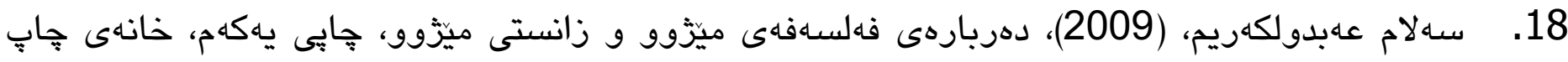
و پِهخى رِينما، سليّمانى.

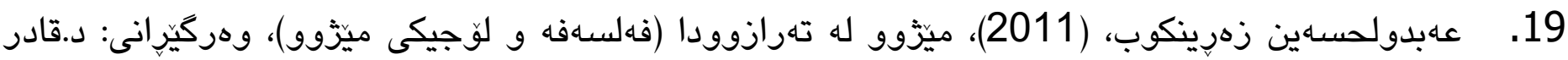

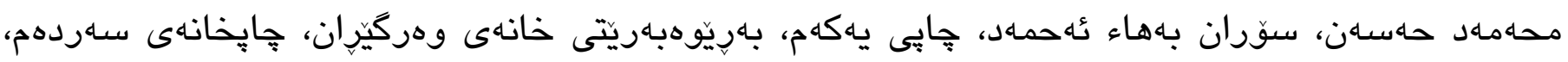

سليمانى.

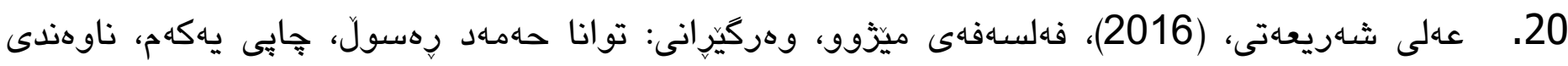
سايه، سليمانى، 2016.

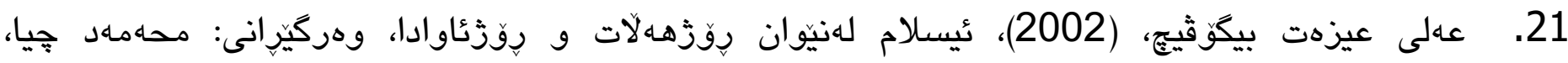

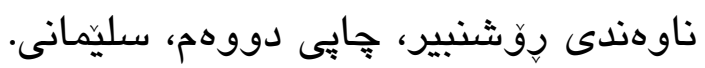

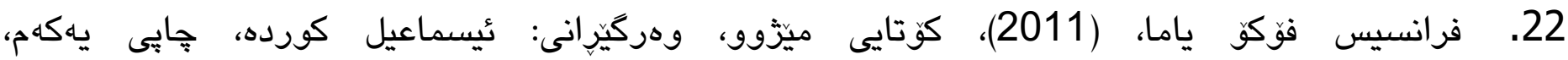

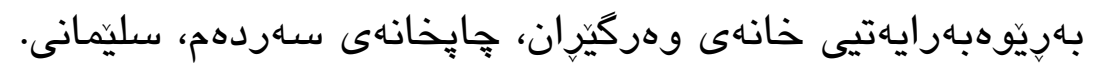

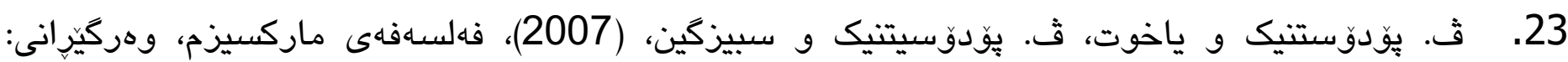

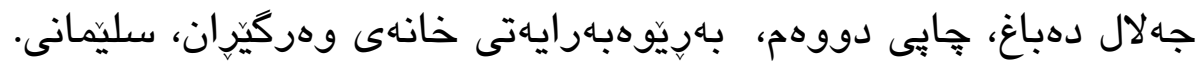

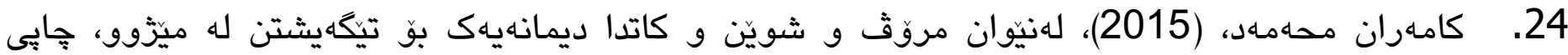

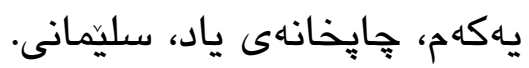

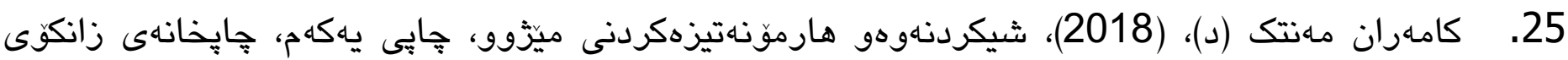
سالاحهدين، هـوليّر.

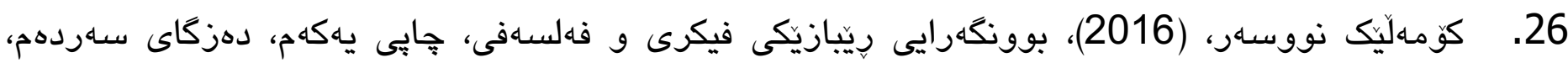
سليمانى.

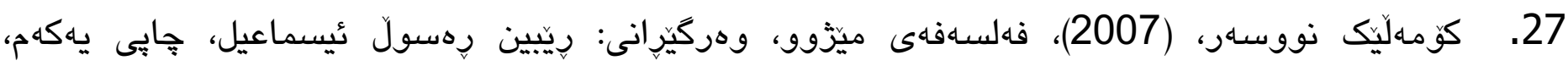

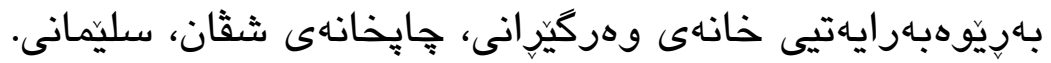

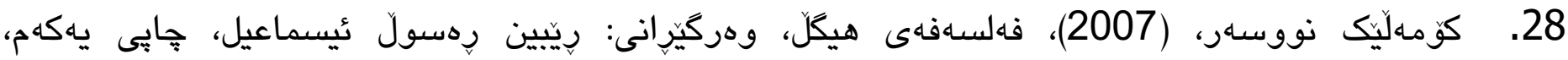

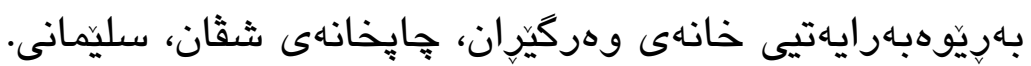

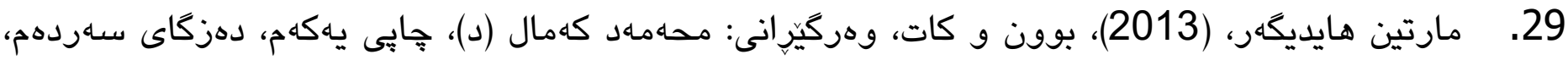
سليمانى.

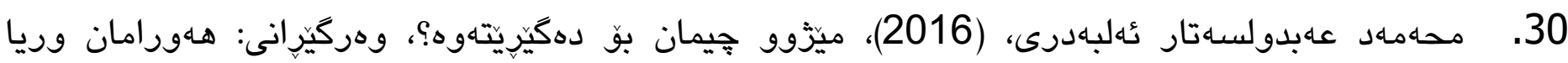

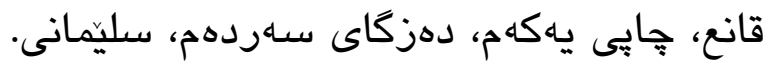

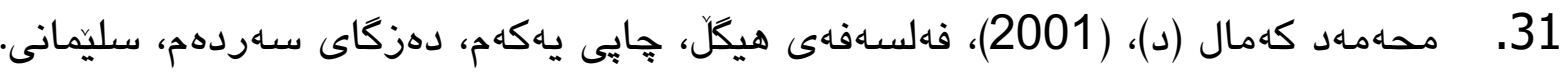

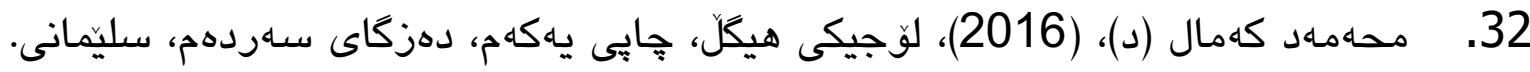

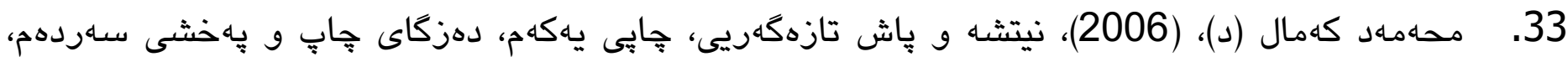
سليمانى.

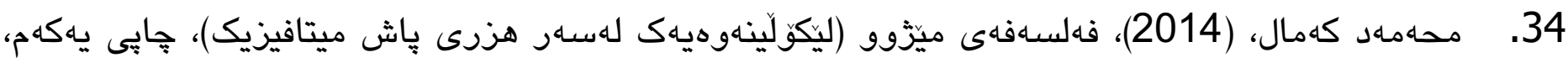
ناوهندى عئنديثيه، سليمانى. 
35. مستها غالب، (2008)، فريدريش نيجه، وهركيّرانى: سامان عهلى حاميد، جابيى يهكهم، جإِخانهى كَنج، سليمانى.

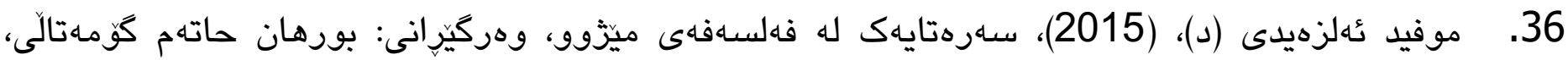

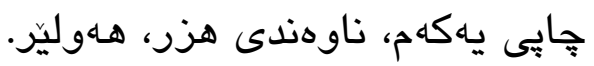

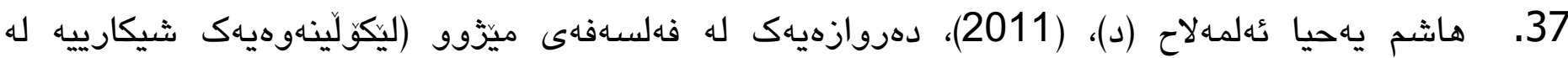

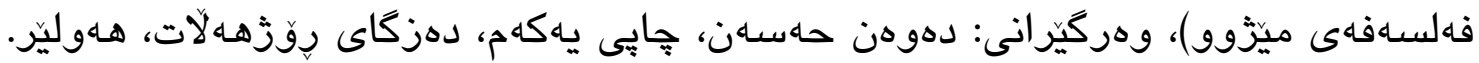

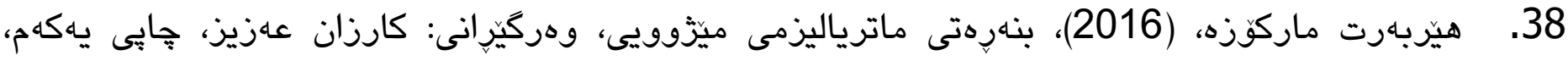

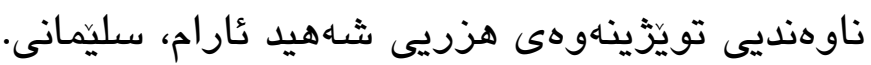

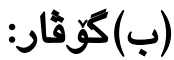

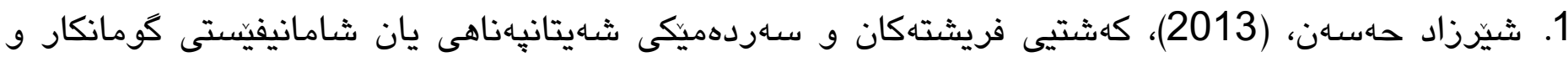

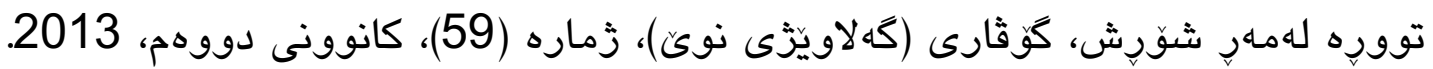

\section{دوومم/ به زمانى عهرهب؟}

(أ) كثيب:

1. أحمد عبدالحليم عطية (د)، (2011)، ليوتار والوضع مابعد الحداثي، الطبعة الاولى، دار الفارابي، بيروت- لبنان.

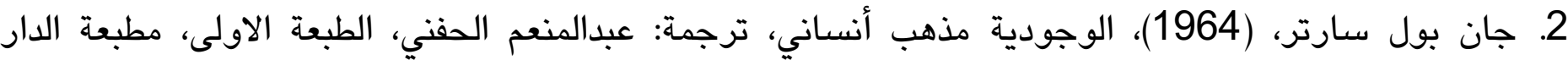
المصرية. (- مان.

3. جون ماكوري، (1982)، الوجودية، ترجمة: امام عبدالفتاح امام (د)، مراجعة: فؤاد زكريا (د)، سلسلة عالم

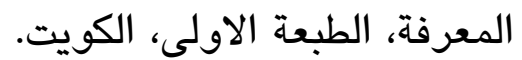

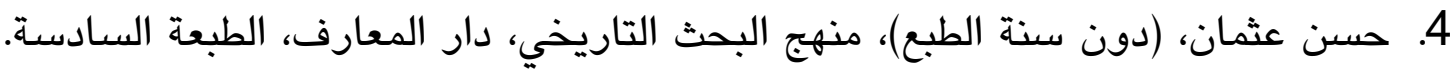

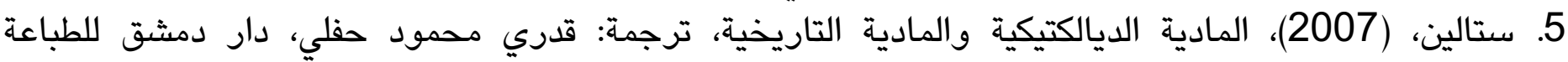
و والنشر، مصر. 6. صفاء عبدالسلام جعفر(د)، (1998)، قراءة للمصطلح الفلسفي، ترجمة واعداد: الطبعة الاولى، دار الثقافة العلمية، الاسكندرية.

7. قيس حاتم هاني الجنابي (د)، (2016)، فلسفة التأريخ، الطبعة الاولى، الدار المنهجية للنشر والتوزيع، عمان.

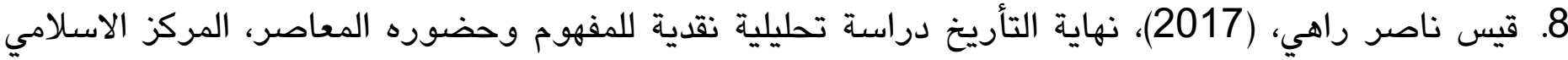

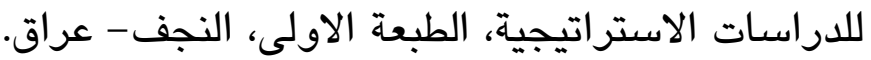

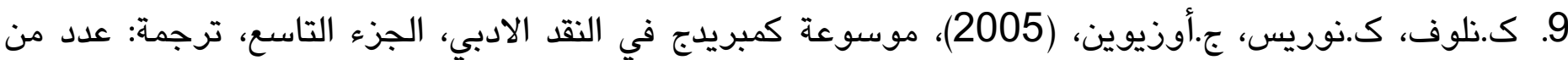
المترجمين، الطبعة الاولى، المجلس الاعلى للثقافة، القاهرة. 10. محمد جلوب فرحان، الفيلسوف والتاريخ نماذج من التأويل الفلسفي للتاريخ، الطبعة الاولى، منشوران مكتبة بسام، موصل، 1987. 
11. محمد سليمان حسن، (2008)، دراسات في الفلسفة الأوروبية، دار علاء الدين، الطبعة الاولى، سورية-

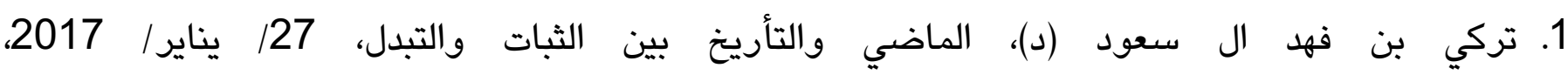
http://www.aleqt.com/2017/01/27/article_1127346.html

2. محمد جلوب الفرحان (د)، تأمل في بعض مناحي فلسفة التأريخ، مجلة الفيلسوف- مجلة فلسفية الكترونية،

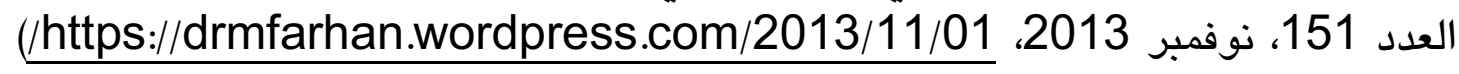

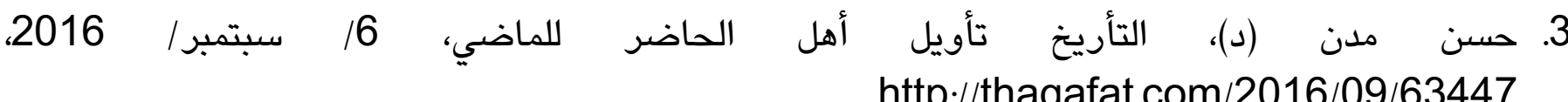
http://thaqafat.com/2016/09/63447

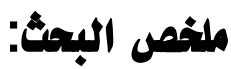

ان هذا البحث الموسوم بـ((التأويلية الوجودية للتأريخ في رواية سفينة الملاك لـ(بختيار علي)) عبارة عن جهد لدراسة الاحداث التأريخية في سياق نص الرواية انفة الذكر، من حيث الفلسفة الوجودية ومعتمدة الودية

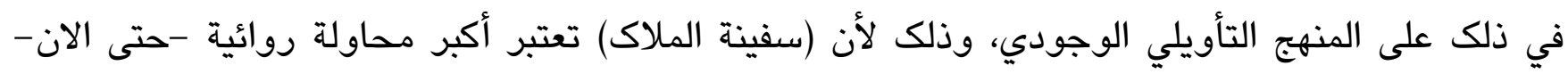
لكاتبه (بختيار علي).

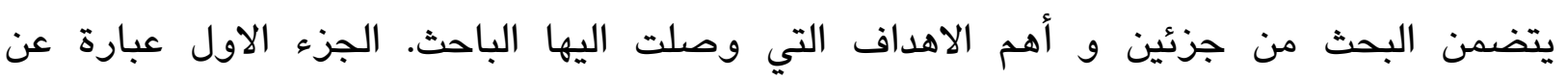

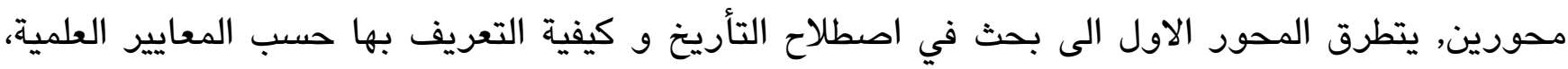
اما المححور الثاني فيتحدث عن أهم المذاهب الفلسفية ومنظوراتهم الخاصة بكيفية تعريف مفهوم التأريخ وتحديد اصطلاحها.

ويتكون الجزء الثاني من هذا البحث، من أربع محاور. يختص المحور الاول بتوضيح عام لمنظور

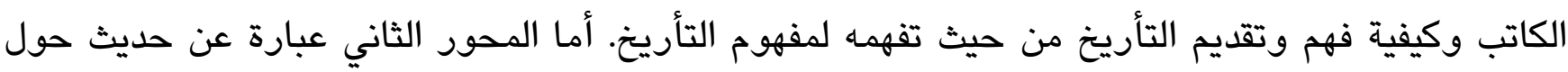
تاريخانية الوجود الانساني وكيفية الوصول الى الوجود هذه، ويدور المحور الرابع حول موضون تلفهية مسألة

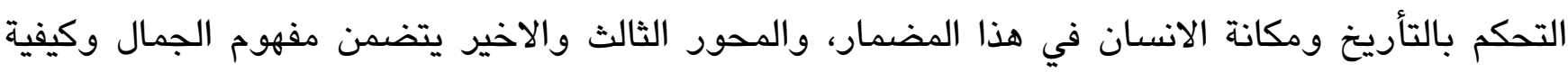
النجاة بها الى بر الامان وتليها النقاط المستخلصة من البحث مع قائمة بالمصادر المختلفة وملخص بالفي باللغتين العربية والانجليزية. 


\section{Abstract:}

This research, which is entitled "Existentialism Interpretation of the history in the story of Angel Ship's by (Bakhtiar Ali)) represents an effort to the study of the historical event through the context of the novel in terms of Existentialism philosophy and based on the Existentialism method of intrtpretation because the novel (Angel's Ship) is considered as the biggest novel attempt by it's author so far.

The research consists of two sectons and the most important objective that the researcher has reached. The first section consists of two axes. The first one deals with the terminology of history and the ways to define it according ti the scientific criteria while the second one deals with the most important philosophical doctrines and their perspectives with defining it`s terminology.

The second section of the research consists of four axes. The first one deal with clarifying the author's perspective and how to comprehend and present history. The second one is about the historical human existence and the ways to reach this existence. The third one deals with the subject of controlling the history and the human status in this field. The fourth one consists of the concept of beauty nd how to lead it to the safety, followed by the results that have been reached with the list of the different references and abstract in both languages: Arabic and English. 